\title{
THE DISSOCIATION AND
}

ASSOCIATION BEHAVIOUR

OF YEAST RIBOSOMES

j.a.l.i. walters 

THE DISSOCIATION AND ASSOCIATION BEHAVIOUR

OF

YEAST RIBOSOMES 
Promotor:

Prof. Dr. G.A.J. van Os 
THE DISSOCIATION AND ASSOCIATION BEHAVIOUR OF YEAST RIBOSOMES

\section{P R O E F S C H R I F T}

TER VERKRIJGING VAN DE GRAAD VAN DOCTOR IN DE WISKUNDE EN NATUURWETENSCHAPPEN

AAN DE KATHOLIEKE UNIVERSITEIT TE NIJMEGEN, OP GEZAG VAN

DE RECTOR MAGNIFICUS DR. G. BRENNINKMEYER,

HOOGLERAAR IN DE FACULTEIT DER

SOCIALE WETENSCHAPPEN, VOLGENS BESLUIT VAN DE SENAAT

IN HET OPENBAAR TE VERDEDIGEN

OP VRIJDAG 12 DECEMBER 1969,

DES NAMIDDAGS TE 2 UUR PRECIES

door

JOHANNES ALOYSIUS LEONARDUS IGNATIUS WALTERS

Geboren te 's-Hertogenbosch

Druk: Offsetdrukkerij Faculteit der Wiskunde en Natuurwetenschappen

Nijmegen 
Erasmus, sprekend over de beoefenaren der natuurwetenschappen:

"Gelukkig voor hen vinden ze meestal nog lieden die hen geloven ook!" Uit: "De lof der zotheid" 
Aan mijn ouders 



\section{Contents}

Preface 1

Chapter I Chemical composition and structure of ribosomes 3

1.1. Introduction 3

1.2. The ribosomal ribonucleic acid 6

1.3. The ribosomal proteins 8

1.4. The internal organisation of ribosomes 9

Chapter II The dissociation and association behaviour of yeast ribosomes 13

$\begin{array}{ll}\text { 2.1. Introduction } & 13\end{array}$

2.2. Materials and methods $\quad 15$

2.2.1. Materials 15

2.2.2. Methods 16

2.2.2.1. Isolation of ribosomes and ribosomal subunits $\quad 16$

2.2.2.2. Equilibrium dialysis 16

2.2.2.3. Analytical ultracentrifugation 17

2.2.2.4. Determination of free and bound magnesium ions $\quad 17$

2.2.2.5. pH-measurements and hydrogen ion titrations 18

$\begin{array}{ll}\text { 2.2.2.6. Optical measurements } & 18\end{array}$

2.3. Results 18

2.4. Discussion 29

2.4.1. Dissociation-association and charge 29

2.4.1.1. The effect of monovalent cations 29

2.4.1.2. The effect of divalent cations 30

2.4.2. The hysteresis 31

2.4.3. Heterogeneity 34

2.4.4. The possible existence of a dissociation factor 34

Chapter III Binding of magnesium ions to yeast ribosomes 39

3.1. Introduction 39

3.2. Materials and methods $\quad 39$

3.3. Theoretical aspects $\quad 40$ 
3.4. Results

3.5. Discussion

3.5.1. The nature of the binding of magnesium ions to yeast ribosomes

3.5.2. Two classes of binding sites

51

3.5.3. The effect of monovalent cations

Summary

Samenvatting 
Preface

Many biological systems seem to need divalent cations for their structural integrity and functioning. For instance many enzymatic reactions can only occur when divalent cations are present (see for instance ref.1). The binding of messenger $\mathrm{RNA}^{2}$ (RNA = ribonucleic acid) and transfer $\mathrm{RNA}^{3}$ to ribosomes is also critically dependent upon the magnesium ion concentration. Even a magnesium-induced miscoding seems possible ${ }^{4}$. The role of divalent cations, in particular magnesium ions, in stabilizing ribosomes was detected by Chao 5 . Since his paper has been published, it is generally thought that the ribosomal subunits are linked together by magnesium ions. In more recent years it has been suggested that other types of bonds, such as hydrogen bonds or bonds of peptide nature, may also play a role in holding the ribosomal subunits together (for refs. see chapter II).At present the picture is rather complex. For biochemists a detailed knowledge about the bonds involved and about the mechanism of the dissociation and association reactions seems important, since these reactions play an important role in the biosynthesis of proteins. On the other hand the problem is interesting from a physicochemical point of view, because it can be expected that physico-chemical experiments can give a lot of information about the questions mentioned above. In this thesis we have investigated especially the dissociation and association reactions of yeast ribosomes from a physico-chemical point of view. We did not concern ourself with the biological significance of the problem.

In chapter I a survey of the chemical composition and the structure of ribosomes is given.

Chapter II deals especially with the function of magnesium ions in holding the ribosomal subunits together. To elucidate this problem some related studies, such as the dissociation as a function of the $\mathrm{pH}$ and some experiments with other divalent cations appeared necessary. Using some assumptions concerning the binding of magnesium ions, a hypothesis conceming the dissociation-association reactions could be developed.

Chapter III describes a theoretical and experimental analysis of the binding of magnesium ions by yeast ribosomes. This study was undertaken in an attempt to prove the assumptions made in chapter II. 


\section{References}

1. H.R. Mahler and E.H. Cordes, Biological Chemistry, Harper and Row, New York, 1967.

2. T. Okamo to and M. Takanami, Biochim. Biophys. Acta, 76 (1963) 266.

3. M. Cannon, R. Krug and W. Gilbert, J. Mol. Biol., 7 (1963) 360.

4. S. Nishimura, F. Harada and M. Hirabayashi, J.Mol. Biol., 40 (1969) 173.

5. F.C. Chao, Arch. Biochem. Biophys., 70 (1957) 426. 


\section{CHAPTER I}

\section{CHEMICAL COMPOSITION AND STRUCTURE OF RIBOSOMES}

\subsection{Introduction}

In all living cells, especially in those of rapidly growing or metabolic active organisms, small particles are found, which consist of ribonucleic acid (RNA) and protein. These particles are called ribosomes. They play a very important role in the biosynthesis of proteins. The active unit is a cluster of ribosomes, joined together by a molecule of messenger RNA. Such a unit is called a heavy ribosome, polysome, polyribosome or ergosome. According to the codes of genetic information, the amino acids, attached to transfer RNA, are arranged in a definite sequence, using messenger RNA as a template, and polymerized into a specific protein. (For extensive reviews on protein biosynthesis see for instance refs. 1 - 2).

It is a striking fact that ribosomes, originating from very different types of cells and organisms, yet have about the same physical and chemical properties. They are nearly spherical, highly porous and contain a large amount of bound water. The diameter is about $200 \AA$ They are roughly composed of equal parts of RNA and protein. Their molecular weight is about 3 - 4 millions. A ribosome is composed of two subunits with a molecular weight ratio of about $1: 2$. Both subunits have about the same RNA/protein ratio as the total particle. Each subunit probably contains one high molecular weight RNA-chain and many different protein-chains. In addition, a relatively small RNA molecule seems to be a universal constituent of the large ribosomal subunit. ${ }^{3}$ Fig. 1.1. shows an electron micrograph of rat liver ribosomes. The groove dividing the particle into two unequal parts is easily detectable.

In spite of the overall similarity of all ribosomes there are some differences, so that usually two classes are distinguished. Mostly these two classes are named after their sedimentation coefficients - $70 S$ and $80 S$ respectively defined as the sedimentation velocity per unit of centrifugal field and given in Svedberg-units ( $1 \mathrm{~S}=10^{-13} \mathrm{sec}$.). The $70 \mathrm{~S}$ ribosomes are chiefly found in bacteria and chloroplasts, while the $80 \mathrm{~S}$ ribosomes occur in the cytoplasm of vegetable and animal cells. Table 1.1 shows the most important data of both types of ribosomes; those of yeast are given separately because all experiments described in the present study were performed with ribosomes isolated from baker's yeast (saccharomyces cerevisiae). 


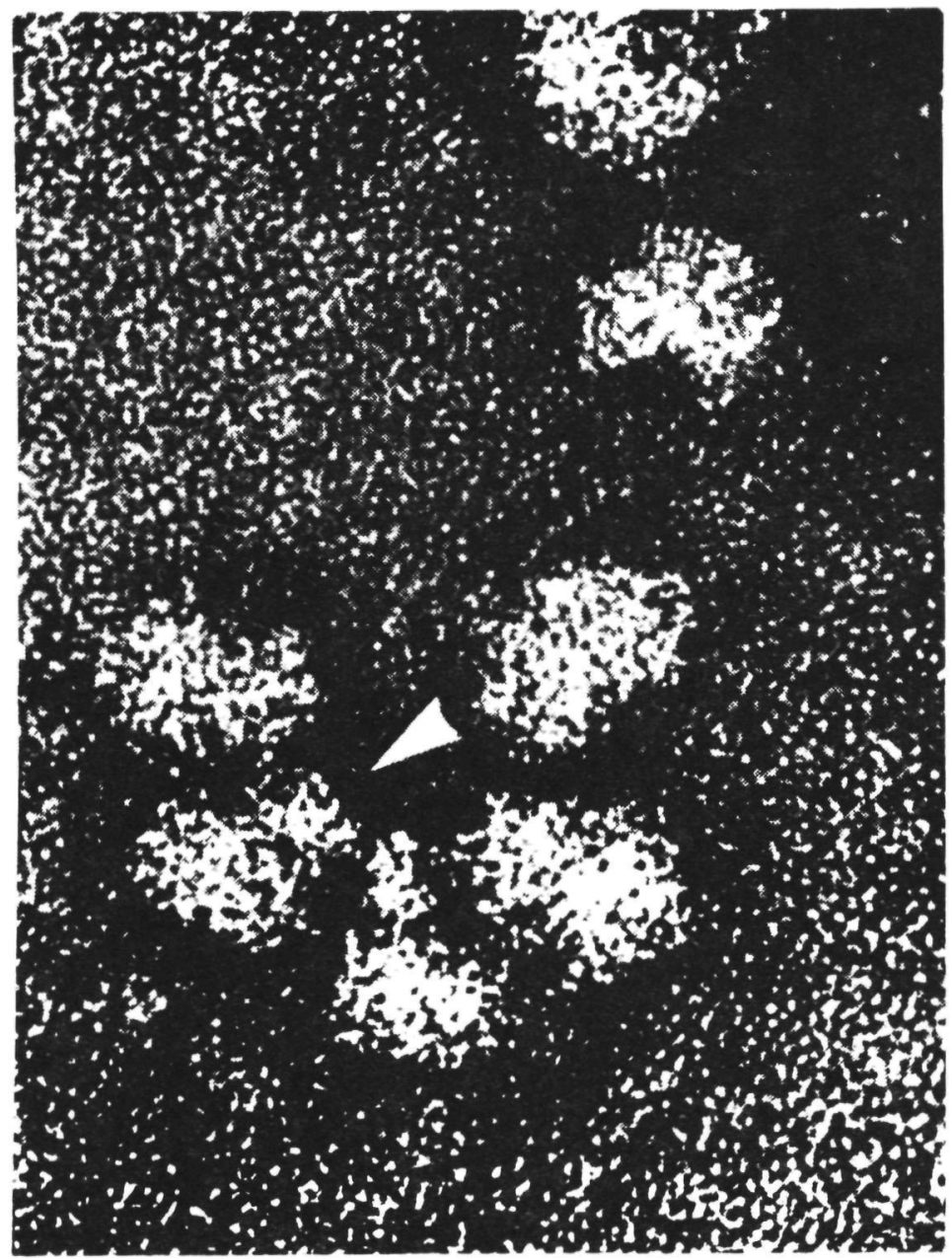

Fig.1.1. Electron micrograph of rat liver ribosomes, spread on carbon film and stained with uranylacetate (Reproduced from E.L. Benedetti, H. Bloemendal and W.S. Bont ${ }^{4}$, with permission of the authors). 


\begin{tabular}{|l|l|l|l|}
\hline \multirow{2}{*}{} & \multirow{2}{*}{$70 \mathrm{~S}$ ribosomes } & \multicolumn{2}{|c|}{80 S ribosomes } \\
\cline { 3 - 4 } & & yeast & \multicolumn{1}{|c|}{ other sources } \\
\cline { 3 - 4 } mol. weight & $(2.8-3) \times 10^{6}$ & $4.1 \times 10^{6}$ & $(4-5) \times 10^{6}$ \\
RNA-content & $60-65^{\circ} \%$ & $42^{\circ} \%$ & $40-45^{\circ} / 0$ \\
protein-content & $35-40^{\circ} \%$ & $58^{\circ} \%$ & $55-60^{\circ} / 0$ \\
diameter & $150-200 \AA$ & $310 \AA$ & $200-300 \AA$ \\
S-value of subunits & $50 \mathrm{~S}(1) 30 \mathrm{~S}(2)$ & $60 \mathrm{~S}(1) 40 \mathrm{~S}(2)$ & $60 \mathrm{~S}(1) 40 \mathrm{~S}(2)$ \\
S-value of RNA-chain & $23 \mathrm{~S}(1) 16 \mathrm{~S}(2)$ & $28 \mathrm{~S}(1) 18 \mathrm{~S}(2)$ & $25-28 \mathrm{~S}(1) 18 \mathrm{~S}(2)$ \\
mol. wt. RNA-chain & $1.1 \times 10^{6}(1)$ & $1.3 \times 10^{6}(1)$ & $(1.3-1.75) \times 10^{6}(1)$ \\
& $0.56 \times 10^{6}(2)$ & $0.72 \times 10^{6}(2)$ & $0.7 \times 10^{6}(2)$ \\
average mol.weight & 20,000 & 15.000 & $12,000-25,000$ \\
proteins & & & \\
\hline
\end{tabular}

(1) = data for large subunit

(2) = data for small subunit

Table 1.1. Physical and chemical properties of various ribosomes (data are taken from references 2,5 and 6 ) 


\subsection{The ribosomal ribonucleic acid}

The ribosomal ribonucleic acid (rRNA) contains the nucleotides of adenine, guanine, uracil and cytosine. Small amounts of pseudouridylic acid and methylated bases are also found. The base composition of rRNA is not complementary for hydrogen bond formation between adenine and uracil or guanine and cytosine. For yeast ribosomes the base composition in molpercent is about: adenine 25.8 , uracil 26.7 , guanine 27.7 and cytosine 19.4 .

The structure of isolated rRNA has been studied by a number of physical and chemical methods, such as sedimentation, ultraviolet dichroism, hypochromicity ${ }^{5}$ and partially degrading of the rRNA. ${ }^{7,8}$ Spirin ${ }^{9}$ has gathered the results into a structural conception, which seems reliable up to now. ${ }^{8}$ rRNA in solution - except in saltfree solution or at high temperature contains double-helical regions, which are joined by single stranded links. The packing of the helical regions depends on ionic strength and temperature. Fig.1.2. shows the model according to Spirin. The helical fragments have been isolated by some investigators, using partial degradation of the rRNA by alkaline hydrolysis 7,8 or enzymatic degradation.
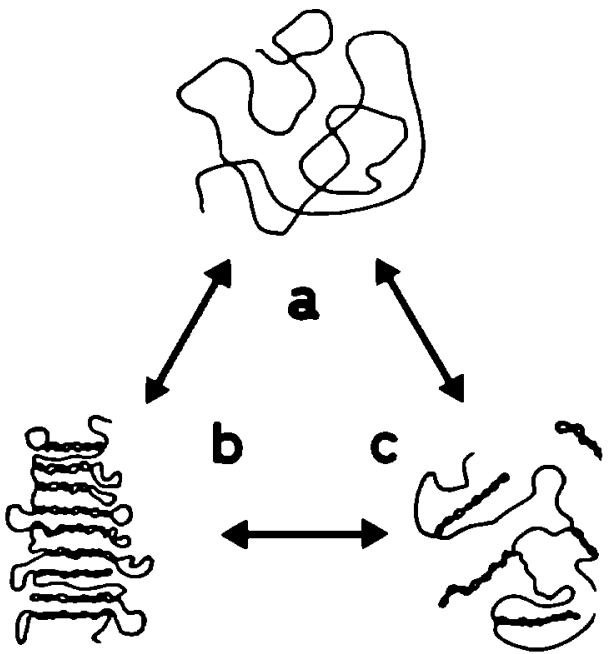

Fig.1.2. Possible configuration of rRNA in aqueous solution according to Spirin?.

Figure Configuration

a

b

c random coil

compact rod

compact coil
Ionic strength

low

low

high
Temperature

high

low

low 
There are indications that these helical fragments only contain complementary pairs of bases. ${ }^{8}$ Little can be said with regard to the length of the helical regions. The results strongly depend on the technique used and vary from about $30 \AA$ to about $120 \AA$ (a survey has been given by Spencer ${ }^{8}$ ).

Information about the structure of rRNA in the intact ribosomes has mainly been obtained from a comparison with isolated IRNA. The striking similarity of the hypochromicity upon hydrolysis or heating ${ }^{10}$, X-ray diffraction pattems ${ }^{5}$ of wet gels and optical rotatory dispersion 11 of ribosomes and isolated rRNA tends to the conclusion that the helical content of IRNA in the intact ribosomes is (almost) the same as in isolated rRNA. However, Furano et al. ${ }^{12}$ concluded from spectrophotometric titrations of ribosomes and isolated rRNA with acridine orange, that "rRNA in the ribosomes has little double helical character, much less, in fact than isolated ribosomal RNA", but Cotter et al. 10 showed that the interpretation of Furano is not justified if rRNA in the intact ribosomes has a less flexible structure than isolated rRNA. The fact that the S-values of isolated rRNA at zero concentration, in contrast with those of ribosomes, strongly depend on the composition of the solvent ${ }^{5}$ supports the idea of a more rigid structure of rRNA in the intact ribosomes. From X-ray analysis it has been concluded that a ribosome contains four or five parallel double helices, 45 to $50 \AA$ apart. ${ }^{5}$

It is almost generally accepted that each ribosomal subunit contains one high molecular weight RNA-chain. However, a conversion of the heavier RNA component into the lighter one has been observed, ${ }^{13}$ suggesting that the heavier component might consist of two subunits. The fact that the base composition of the rRNA's of the two ribosomal subunits is not identical ${ }^{14}$ seems to rule out the possibility that the rRNA of the large subunit is composed of two molecules, which are identical with the rRNA-chain of the small subunit. Another indication which supports this conclusion will be mentioned in section 1.3. Midgley ${ }^{15}$ suggested that the heavier rRNA component consists of two RNA-chains, "joined together by bonds unlike those of the phosphodiester type found in the constituent polynucleotides".

It is noteworthy that there are several indications for heterogeneity of the rRNA. ${ }^{16,17}$ Heterogeneity has been mentioned for the rRNA-chains of both subunits. The significance of this phenomenon is still not known. 


\subsection{The ribosomal proteins}

Amino acid analysis of the ribosomal proteins have shown that these proteins are rich in basic amino acids. The different protein chains have a great affinity for each other. They are small in molecular weight, about 15,000 for the protein chains of yeast ribosomes. ${ }^{10}$ From the mol. weight and the protein content of yeast ribosomes a number of 150 protein chains per ribosome can be calculated. Electrophoretically it has been shown that the protein chains of the ribosomal subunits of Escherichia coli (E.coli) are not identical. ${ }^{18}$ For the proteins of yeast ribosomes only incomplete data are available. ${ }^{19}$ The function of all these proteins is poorly understood. A rough division in three classes can be made:

1. Weakly bound proteins. These proteins can be removed, for instance with DEAE-cellulose. The remaining particles have retained their protein synthesising capacity.

2. Proteins which can reversibly be removed with a solution of $5 \mathrm{M} \mathrm{CsCl}$. These proteins are called "splitproteins".

3. The remaining proteins are called "coreproteins". Originally it was believed that these proteins could not be removed reversibly.

Though Traub c.s. ${ }^{20}$ succeeded in removing and recombining the proteins of the third group - making the division meaningless - the terms "split" proteins and "core" proteins are still used.

From their experiments Traub c.s. ${ }^{21}$ concluded that "chemically distinct proteins are also functionally distinct. Thus, the physical heterogeneity of the ribosomal proteins reflects the highly organized functional structure of the ribosomes". As an important result of these investigations it appeared that the proteins of the two subunits can not be interchanged. In addition, the original 16S rRNA (the rRNA of the small subunit of E.coli ribosomes) can not be replaced by a $16 \mathrm{~S}$ rRNA obtained from degraded 23S rRNA (the rRNA of the large subunit of E.coli ribosomes). In spite of the excellent experiments of Traub c.s. it remains obscure whether the ribosomal proteins have a direct function in the biosynthesis of proteins. It seems quite possible that the ribosomal protein has an important function in maintaining a rigid secondary and tertiary structure of the rRNA. 


\subsection{The internal organization of ribosomes}

Titrations of ribosomes with acridine orange showed that the amount of bound dye is independent of the protein content of the ribosomes. In addition there is a close correlation between the RNA-content and the amount of bound dye. Both facts suggest that the dye is bound by the RNA. About 90 percent of the RNA can be titrated with acridine orange. This basic dye can easily be displaced by polylysine ${ }^{12}$. Moreover, only a small amount of the ribosomal proteins is displaced by acridine orange. From this facts it has been concluded that the exterior of the ribosomes largely consists of RNA, or at least, that the RNA is readily accessible for molecules of the environment.

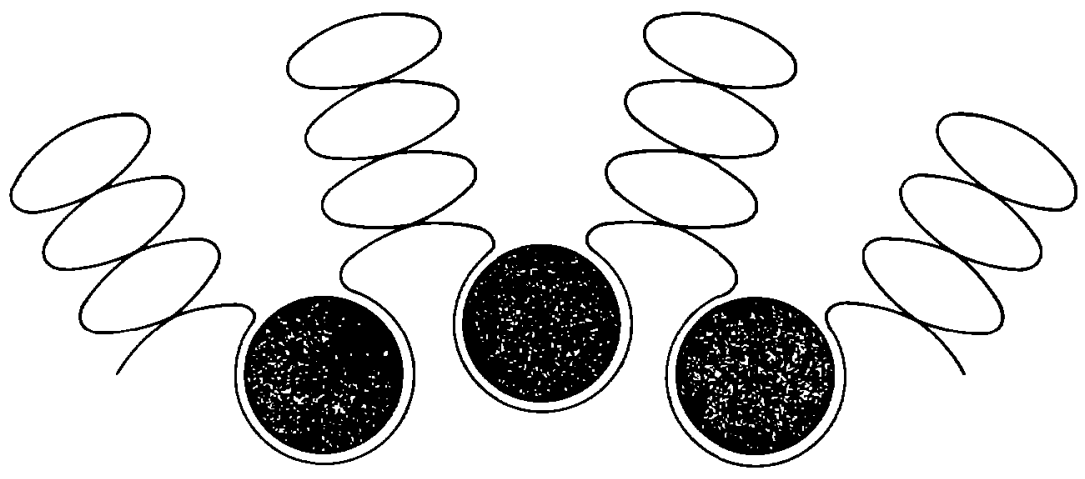

Fig.1.3. Schematic model of ribosome structure following Cotter et al ${ }^{10}$. The shaded spheres represent the protein, attached to the non-helical regions of the IRNA in the interior of the ribosome.

As already mentioned in section 1.2. the rRNA partially consists of double-helical regions. (Cotter et al. ${ }^{10}$ estimated a helix content of about 60 percent for yeast rRNA). The double helical state of nucleic acids is stabilized by binding of basic polymers. This is reflected in a rise of the melting temperature. Ribosomal proteins are basic polymers. Nevertheless the melting curves of ribosomes and isolated rRNA practically coincide, indicating that ribosomal proteins do not stabilize the double-helical state of the rRNA. Hence it may be stated that the ribosomal proteins are not bound to the double-helical regions of the rRNA. (see also refs.11 and 22) Using known numerical data, such as the number of nucleotides in a ribosome, the percentage non-helical 
nucleotides, the diameter of the globular ribosomal [.lusuess, and the repeat distance of a nucleotide chain, Cotter et al. calculated that the greater part of the non-helical nucleotides might be involved in fixation of the proteins. Using these and other arguments, Cotter et al. suggested a model of ribosome structure as presented in fig. 1.3. The model of Cotter accounts for the remarkable resistance of the ribosomes for ribonuclease. As shown by the partial degrading of the rRNA, helical rRNA is much less sensitive to ribonuclease as compared with non-helical rRNA. 
References:

1. G.D. Novelli, Annual Review of Biochemistry, 36 (1967) 449.

2. A.S. Spirin and L.P. Gavrilova, The Ribosome, Springer-Verlag, Berlin, (1969).

3. N. Sarkar and D.G. Comb, J. Mol. Biol., 39 (1969) 31.

4. E.L. Benedetti, H. Bloemendal et W.S. Bont, C.R. Acad. Sci., 259 (1964) 1353.

5. M.L. Petermann, The Physical and Chemical Properties of Ribosomes, Elsevier, Amsterdam (1964).

6. U.E. Loening, J. Mol. Biol., 38 (1968) 355.

7. R.A. Cox, H.J. Hannah and K. Kanagalingam, Biochem. J., 106 (1968) 773.

8. M. Spencer, J. Chim. Phys., 65 (1968) 190.

9. A.S. Spirin, Progress in Nucleic Acid Research, 1 (1963) 301.

10. R.I. Cotter, P. McPhie and W.B. Gratzer, Nature, 216 (1967) 864.

11. P.K Sarkar, J.T. Young and P. Doty, Biopolymers, 5 (1967) 1.

12. A.V. Furano, D.F. Bradley and L.G. Childers, Biochemistry, 9 (1966) 3044.

13. R.G. Tsanev and G.C. Russev, Febs Letters, 1 (1968) 104.

14. F. Amaldi, Nature, 221 (1969) 95.

15. J.E.M. Midgley, Biochim. Biophys. Acta, 108 (1965) 348.

16. R.J. Young, Biochemistry, 7 (1968) 2263.

17. E.L. Michelson and Y. Suyama, Biochim. Biophys. Acta, 157 (1968) 200.

18. R.F. Gesteland and Th. Staekelin, J.Mol. Biol., 24 (1967) 153.

19. J. Schmidt and B.R. Reid, Biochem. Biophys. Res. Com., 31 (1968) 654.

20. P. Traub and M. Nomura, Proc. Natl. Acad. Sci. U.S., 59 (1968) 777.

21. P. Traub, K. Hosakawa, G.R. Craven and M. Nomura, Proc. Natl. Acad. Sci., U.S., 58 (1967) 2430.

22. L. Daya and W.B. Gratzer, Biochim. Biophys. Acta, 179 (1969) 239. 



\section{CHAPTER II}

\section{THE DISSOCIATION AND ASSOCIATION BEHAVIOUR OF YEAST RIBOSOMES.*)}

\subsection{Introduction}

The fact that ribosomes can dissociate into two subunits and that these subunits can recombine again is well-known nowadays. These dissociation and association reactions play an important role in the biosynthesis of proteins. It has been shown in recent years that the dissociation of ribosomes is an obligatory step in the chain initation (see for instance refs. 1-3). During the process of protein synthesis the larger subunit is attached to the smaller one. So a detailed knowledge about the bonds involved in linking the ribosomal subunits together and about the mechanism of the dissociation and association reactions seems important. At present, however, little is known about these phenomena.

It is generally accepted that divalent cations, especially magnesium ions, or polyamines play an important role in the dissociation and association reactions 4 . The possible interactions between the ribosomal subunits and magnesium ions, which have been discussed in the literature are presented in figure 2.1. The chelate complex formation between magnesium ions, phosphordiestergroups and amino groups agrees with the hypothesis of Zubay ${ }^{6}$ that the aminogroups of the bases are involved in binding magnesium ions. However, at present it is scarcely a subject of discussion that magnesium ions are bound by the phosphate groups 7 . Hence, if magnesium ions have a direct binding function in holding the ribosomal subunits together, there must be a salt bridge between the phosphate groups of the two subunits. The effect of ionic strength and $\mathrm{pH}$ on the dissociation and association behaviour of ribosomes has been mentioned by several workers. These effects have been related to their influence on the amount of bound magnesium ions 4,5 .

In fig. 2.1 the possible role of hydrogen bonds in linking the ribosomal subunits together is also indicated. This idea was supported by the fact that treatment of ribosomal subunits with formaldehyde results in the loss of binding capacity of the subunits 8,9 . Formaldehyde was believed to react with

*) The main results of this chapter will be published elsewhere (J.A.L.I. Walters and G.A.J. van Os, Biochim. Biophys. Acta, in the press). 


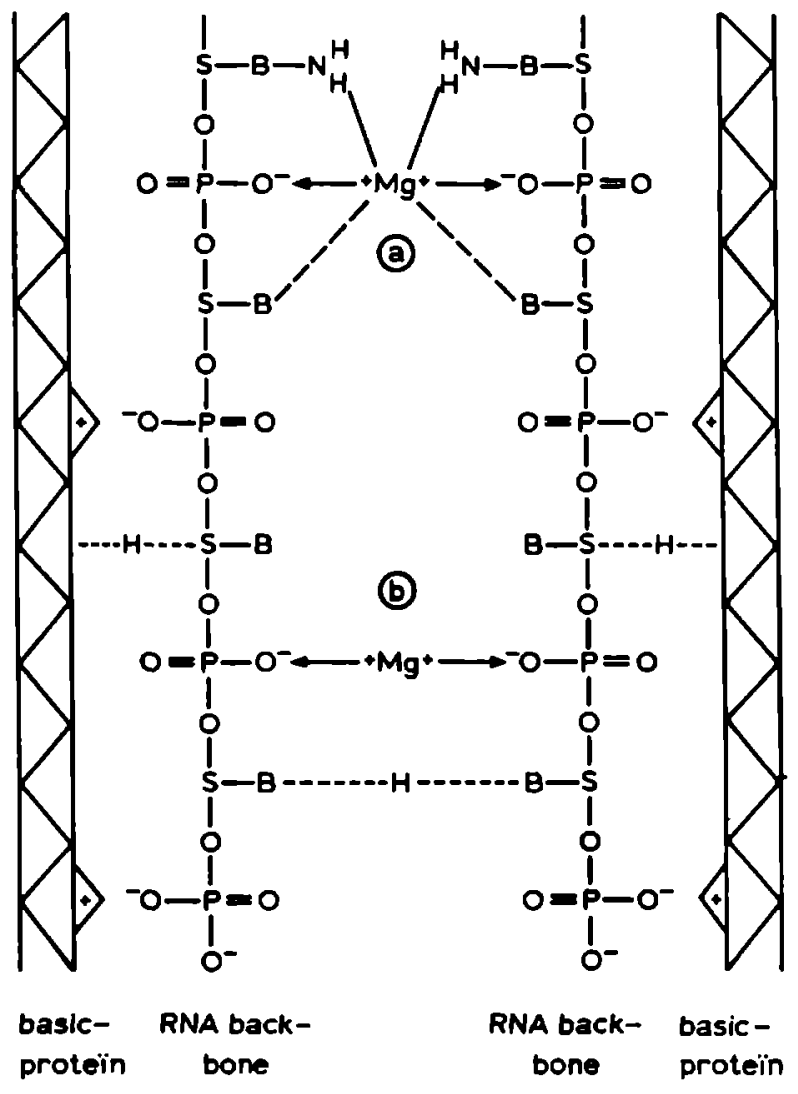

Fig.2.1. Schematic representation of possible complex formation between the RNA-chains of the two ribosomal subunits and $\mathrm{Mg}^{++}$-ions.

$S=$ ribose (deoxyribose)

$\mathbf{B}=$ purine or pyrimidine bases

a = chelate complex formation

$\mathrm{b}=$ electrostatic interaction

(reproduced from A.G.W.J. Lansink ${ }^{5}$, with permission) 
the aminogroups of rRNA. However, the reduction of the binding of magnesium ions to $\mathrm{DNA}^{6}$ and $\mathrm{rRNA}^{5}$ by formaldehyde is a strong indication that the molecular configuration is changed, or that steric hindrance occurs, since magnesium ions do not bind to the aminogroups at all. In the author's opinion experiments with formaldehyde are not conclusive as long as it is unknown how formaldehyde reacts with RNA. The heat-mediated dissociation of ribosomes 10,11 is not incompatible with the idea of hydrogen bonds between the two subunits, though this type of dissociation is not always reversible $^{12}$.

A participation of bonds of peptide nature is suggested by some authors ${ }^{13,14}$. Treatment of ribosomes with papain or trypsin causes dissociation. However, an interpretation of these results is very difficult, since a recombination of the subunits is not possible. The effect of the enzyme is rather drastic. Most probably the enzyme causes an alteration in the ribosomal structure. A role of the SH-groups of the ribosomal proteins in linking the ribosomal subunits together is suggested by Tamaoki and Miyazawa 15,16 . They based their conclusion on experiments with sulphydryl reagents. However, only those ribosomes, that contain 4-thiouridylic acid in their ribosomal RNA are sensitive to a sulphydryl reagent like p-chloromercuribenzoate ${ }^{17}$. A pa -ticip:- $^{-1}$ on of hydrogen bonds between the ribosomal proteins is suggested by Petermann and Pavlovec ${ }^{18}$.

Finally the in vitro dissociation can be caused by a number of reagents, such as nitrogen- and sulfur mustard ${ }^{19}$, polyvinylsulphate 20 and hydrogen peroxide $^{21}$. An explanation of these results at a molecular level is still not possible

In the author's opinion the role of magnesium ions in holding the ribosomal subunits together has never been clarified sufficiently. This chapter deals especially with the function of magnesium ions in the dissociationassociation reactions.

\subsection{Materials and methods}

\subsubsection{Materials}

Ribosomes were isolated from baker's yeast (saccharomyces cerevisiae), purchased as a commercial product from the "Koninlijke Nederlandse Gist- en Spiritusfabrieken" (Delft, the Netherlands). All chemicals were analytical grade (Merck, Darmstadt, Germany). 


\subsubsection{Methods}

\subsubsection{Isolation of ribosomes and ribosomal subunits}

Ribosomes were isolated from baker's yeast according to the method described by Chao and Schachman 22 . Yeast was ground with four parts carborundum (120 mesh). After a grinding of $5 \mathrm{~min}$. two additional parts were added and grinding was continued for $10 \mathrm{~min}$. The mixture was extracted three times with two parts of a phosphatebuffer $\left(2 \times 10^{-3} \mathrm{M}\right.$ phosphate, $\mathrm{pH}=$ 7.4 and $10^{-3} \mathrm{M} \mathrm{MgSO}_{4}$ ). The extraction was carried out over a glass wool filter. The crude extract was centrifugated at $8,000 \mathrm{~g}$ for $25 \mathrm{~min}$. The supernatant, containing the ribosomes, was centrifugated at $100,000 \mathrm{~g}$ for $60 \mathrm{~min}$. The ribosomal pellet was resuspended in the buffer. Finally, the centrifugation procedure was repeated twice. In the first stage of the isolation procedure (grinding with carborundum) purified bentonite (1 gr. per $100 \mathrm{gr}$. yeast) was added to suppress ribonuclease activity. When ribosomes were prepared for hydrogen ion titrations the preparative medium only contained $10^{-3} \mathrm{M}$ $\mathrm{MgSO}_{4}$

Isolation of pure $80 \mathrm{~S}$ ribosomes and a mixture of the $60 \mathrm{~S}$ and $40 \mathrm{~S}$ subunits from a solution containing these three components was performed according to Aronson and McCarthy ${ }^{23}$. The mixture was centrifugated in a swinging bucket rotor for the calculated time to pellet the $80 \mathrm{~S}$ component. The supernatant contains the ribosomal subunits. The pellet was resuspended and the centrifugation procedure was repeated four times. The isolation and purification procedure was performed at $5^{\circ} \mathrm{C}$.

\subsubsection{Equilibrium dialysis}

Dialyses were carried out in Visking dialysis tubing, which before use has been boiled in $0.01 \mathrm{M}$ EDTA-solution and subsequently extensively washed with boiling distilled water. The stock solution of the ribosomes contained about $15 \mathrm{mg}$ ribosomes/ml. For all experiments this stock solution was diluted with a solvent, which had for each sample the desired ionic strength, magnesium ion concentration and $\mathrm{pH}$.

For dissociation-association experiments the stock solution was diluted to a concentration of $0.1 \mathrm{mg}$ ribosomes $/ \mathrm{ml}$. A $1 \mathrm{ml}$ sample was dialysed with magnetic stirring against 11 outer solution of the desired composition. Equili- 
brium was obtained in 12 hours. For safety the samples were analysed after 16 hours. In each case the magnesium ion concentration after the equilibrium dialysis was checked.

For binding experiments the stock solution was diluted to a concentration in the range of 1 to $4 \mathrm{mg}$ ribosomes $/ \mathrm{ml}$. A $3 \mathrm{ml}$ sample was dialysed with magnetic stirring against 11 outer solution. The outer solutions were refreshed twice after 16 and 24 hours respectively. After another 16 hours the magnesium ion concentration of the inner and outer solutions were determined as described below. A Donnan correction was not required, since bound magnesium was found to be independent of the ribosome concentration in the range from 1 to $10 \mathrm{mg} / \mathrm{ml}$.

The concentrations of the ribosomes were determined by the dry weight method. Corrections for added salts were made. In a separate experiment a relation between dry weight and P-content of the ribosomes was determined. It was found that $1 \mathrm{mg}$ ribosomes contains $1.31 \times 10^{-6}$ atom $P$. This relation was used in all other experiments. Phosphorus was determined according to the method of Fiske and Subbarow ${ }^{24}$.

\subsubsection{Analytical ultracentrifugation}

The concentrations of the ribosomes (80S) and the ribosomal subunits (60S and $40 \mathrm{~S}$ ) in a dissociation mixture were determined by analytical ultracentrifugation, which was carried out with a model E Spinco ultracentrifuge, equipped with an electronic recording system for absorption optics as described by van Es and Bont ${ }^{25}$. All runs were performed at $5^{\circ} \mathrm{C}$.

\subsubsection{Determination of free and bound magnesium ions}

The analysis of magnesium ion concentration was carried out with a Techtron model AA-4 atomic absorption spectrophotometer. All samples to be analysed were diluted with a solution of the desired ionic strength to a magnesium concentration in the range of $10^{-5}$ to $5 \times 10^{-5} \mathrm{M}$. The instrument was calibrated with standard solutions of magnesiumsulphate in a solution of the desired ionic strength. The amount of magnesium bound to ribosomes was calculated from the difference between the total concentration of magnesium ions in the intemal and extemal dialysis compartments ( $c_{1}$ and $c_{2} M$ respectively). Using the known concentrations of ribosomes $\left(c_{r} \mathrm{mg} / \mathrm{ml}\right), r$ was cal- 
culated according to the relationship:

$$
r=\frac{2\left(c_{1}-c_{2}\right)}{1.31 \times 10^{-3} c_{r}}
$$

where $r$ is the amount of bound magnesium, expressed in equivalents $\mathrm{Mg}^{++}$ per ribosomal phosphate.

\subsubsection{5. $\mathrm{pH}$ measurements and hydrogen ion titrations}

pH measurements were performed with a Radiometer PHM 4c. Hydrogen ion titrations of ribosomes, suspended in $10^{-3} \mathrm{M} \mathrm{MgSO}_{4}$ were performed according to the method described by de Bruin and van $0 s^{26}$. If $\mathrm{m} \mathrm{mg}$ ribosomes are titrated with $\mathrm{t} \mathrm{M} \mathrm{KOH}$, the change of charge per ribosomalphosphate $(\triangle Z)$ may be calculated according to the relationship:

$$
\Delta \mathrm{z}=-\frac{\mathrm{v} \times \mathrm{t}}{1.31 \times 10^{-3} \times \mathrm{m}} \text {, with }
$$

$\mathbf{v}=$ added volume of titrant in $\mathrm{ml}$.

\subsubsection{Optical measurements}

Optical rotatory dispersion and circular dichroism measurements were carried out with a Jasco spectropolarimeter, model ORD/UV/CD-5. Spectrophotometric titrations were performed with a Zeiss spectrophotometer PMQ II.

\subsection{Results*)}

In the first series of experiments the degree of dissociation ( $\alpha$ ) was determined as a function of the free magnesium ion concentration in $2 \times 10^{-3}$ $\mathrm{M}$ phosphate buffer, $\mathrm{pH}=7.4$. $\alpha$ was calculated from analytical ultracentrifuge recordings. An example is given in fig. 2.2. In this figure the amounts

*) I wish to express my gratitude to Mrs. O.G.U. Janssen-Koel and Mr. J.A. Loontjens for their technical assistance. 


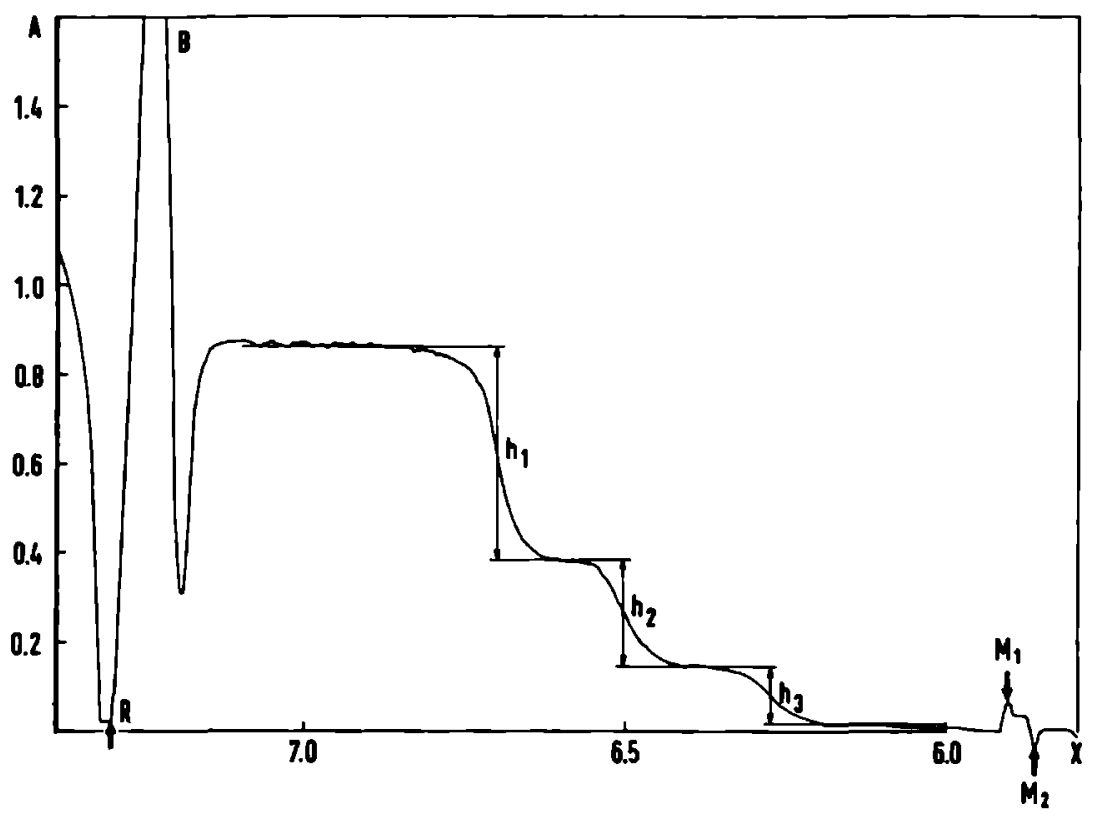

Fig. 2.2. Scan of absorbance A versus radial distance $x$, obtained with yeast ribosomes in phosphate buffer $(\mathrm{pH}=7.4)$ at low magnesium ion concentration.

$R=$ reference point, $B=$ bottom, $M_{1}=$ meniscus, $M_{2}=$ meniscus of reference cell. $h_{1} h_{2}$ and $h_{3}$ are the absorbances of $80 S, 60 S$ and $40 S$ respectively.

of $80 S, 60 \mathrm{~S}$ and $40 \mathrm{~S}$ are indicated by $h_{1}, h_{2}$ and $h_{3}$ respectively. After correction for radial dilution $27, \alpha$ is calculated from the corrected values $E_{1}$, $E_{2}$ and $E_{3}$ respectively, according to:

$$
\alpha=\frac{E_{2}+E_{3}}{E_{1}+E_{2}+E_{3}}
$$

In fig. $2.3 \alpha$ and r are plotted against $\mathrm{pMg}\left(=-\log \left[\mathrm{Mg}^{++} \mathrm{D}\right.\right.$. It is seen that $\alpha$ increases and $\mathrm{r}$ decreases with increasing $\mathrm{pMg}$. At about $\alpha=0.6$ the dissociation curve shows a shoulder. Dilution without changing the composition of the solvent did not have any effect on $\alpha$ In addition, removal of the $60 S$ and $40 S$ subunits by fractional ultracentrifu- 
gation did not cause further dissociation, while the mixture of $60 \mathrm{~S}$ and $40 \mathrm{~S}$ subunits did not recombine to $80 \mathrm{~S}$ ribosomes. From these results it will be clear that at a given $\mathrm{pMg}$ only a part of the ribosomes is able to dissociate. Consequently there must be some kind of heterogeneity in the ribosome population. Decreasing $\mathrm{pMg}$ did not cause an association until about $\mathrm{pMg}=3$. So it follows that the dissociation-association reaction is not an equilibrium reaction. In fig. 2.4. and fig. 2.5. similar experiments are given as in fig. 2.3.

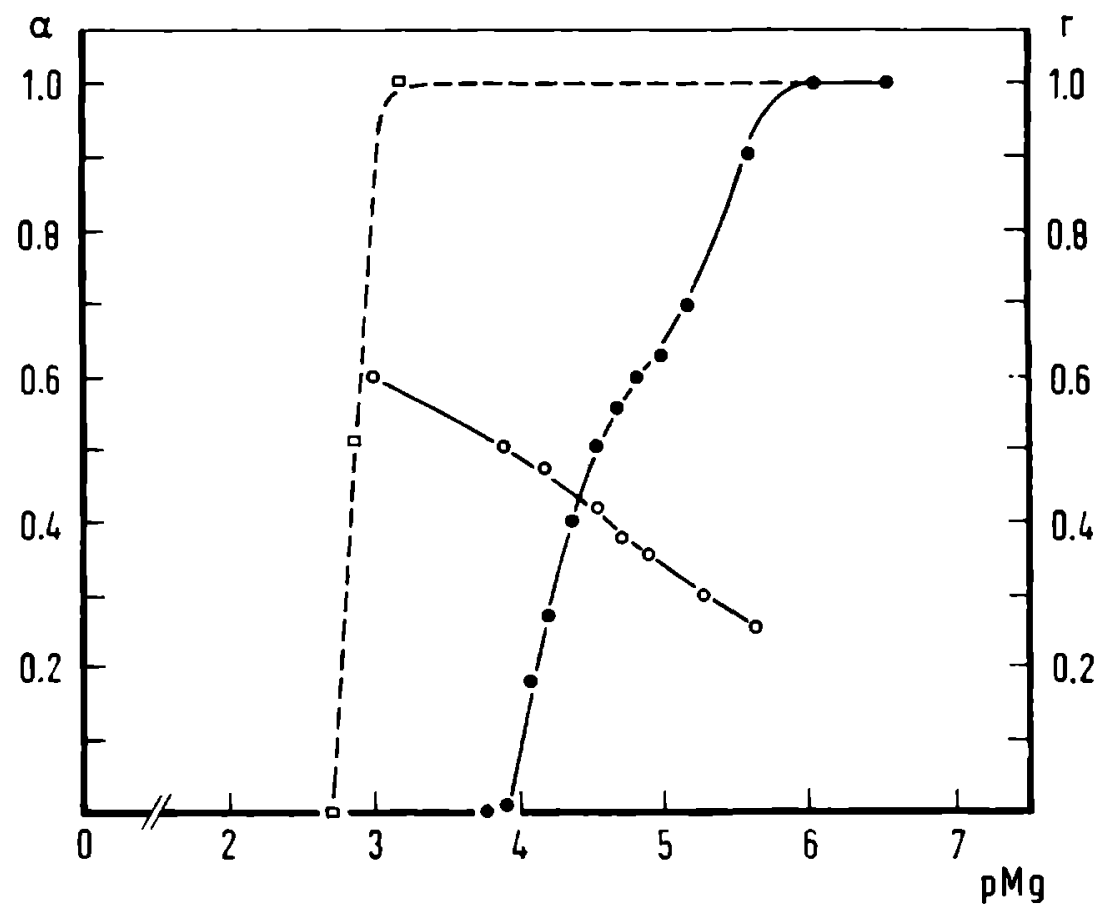

Fig. 2.3. Effect of $\mathrm{pMg}$ on the dissociation of yeast ribosomes and on $\mathrm{Mg}^{++}$-binding to yeast ribosomes in the presence of $2 \times 10^{-3} \mathrm{M}$ phosphate buffer ( $\mathrm{pH}=7.4$ ).

- degree of dissociation ( $\alpha$ ).

- equivalents of bound magnesium per ribosomal phosphate (r).

D degree of dissociation $(\alpha)$ in recombination experiment. 
The only difference is in the concentration of the phosphate buffer, being $7 \mathrm{x}$ $10^{-3} \mathrm{M}$ and $10^{-2} \mathrm{M}$ respectively. Again, as in fig.2.3, a shoulder is found in these two figures, while in fig. 2.5 the curve of $\mathrm{r}$ versus $\mathrm{pMg}$ also shows an inflection point. The inflection points in both curves of fig. 2.5 are within the same $\mathrm{pMg}$ region.

From the given figures $\alpha$ can be found as a function of the charge $Z$, expressed in equivalents $\mathrm{Mg}^{++}$per ribosomal phosphate. At a chosen $\mathrm{pMg}$ the corresponding $\alpha$ and $\mathrm{r}$ are read from the curves, while $Z$ is determined from $Z$ $=\mathrm{r}-1$ ( $\mathrm{Z}$ ranges from 0 to -1$)$. It should be noted that in this calculation procedure the charge of the ribosomal proteins is not taken into account. In fact this means that the charge of the ribosomal proteins is arbitrarily chosen

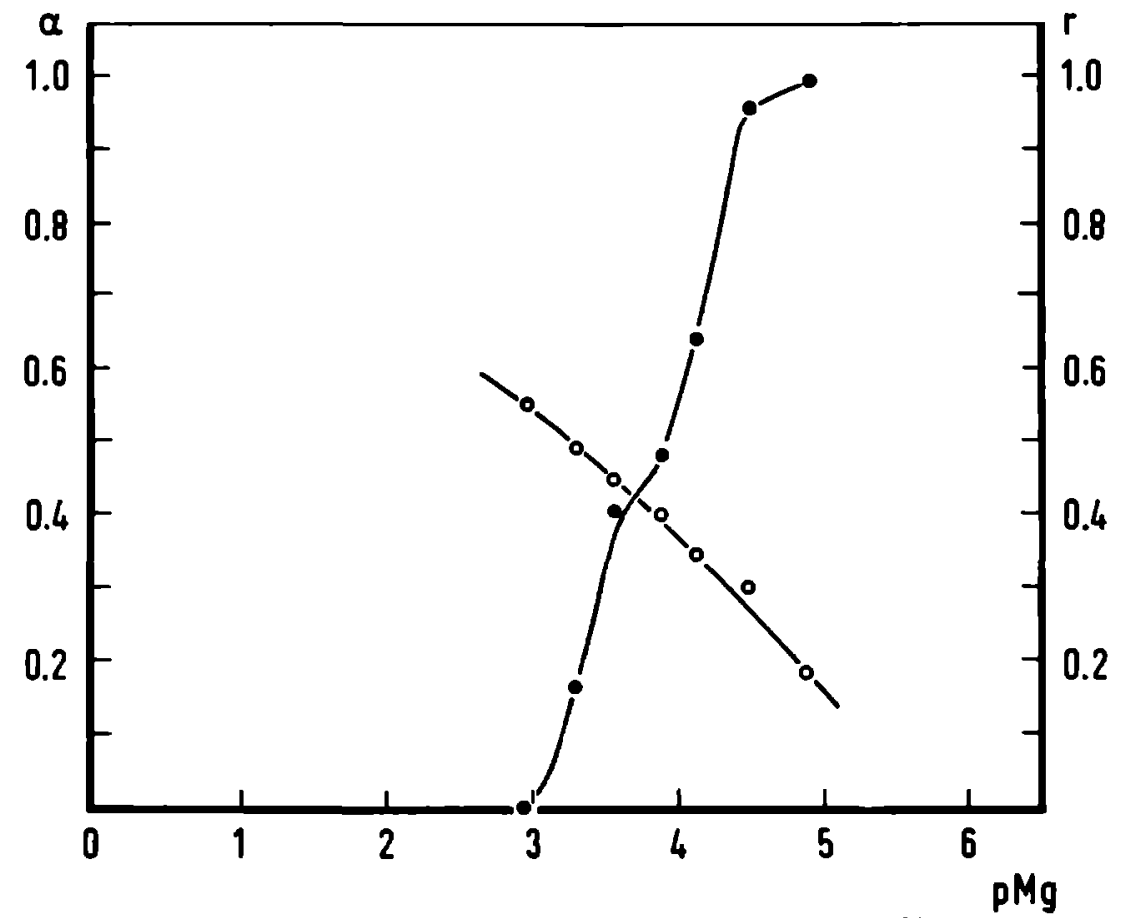

Fig.2.4. Effect of $\mathrm{pMg}$ on the dissociation of yeast ribosome and on $\mathrm{Mg}^{++}$binding to yeast ribosomes in the presence of $7 \times 10^{-3} \mathrm{M}$ phosphate buffer $(\mathrm{pH}=7.4)$.

- degree of dissociation ( $(\infty)$.

- equivalents of bound magnesium per ribosomal-phosphate (r). 


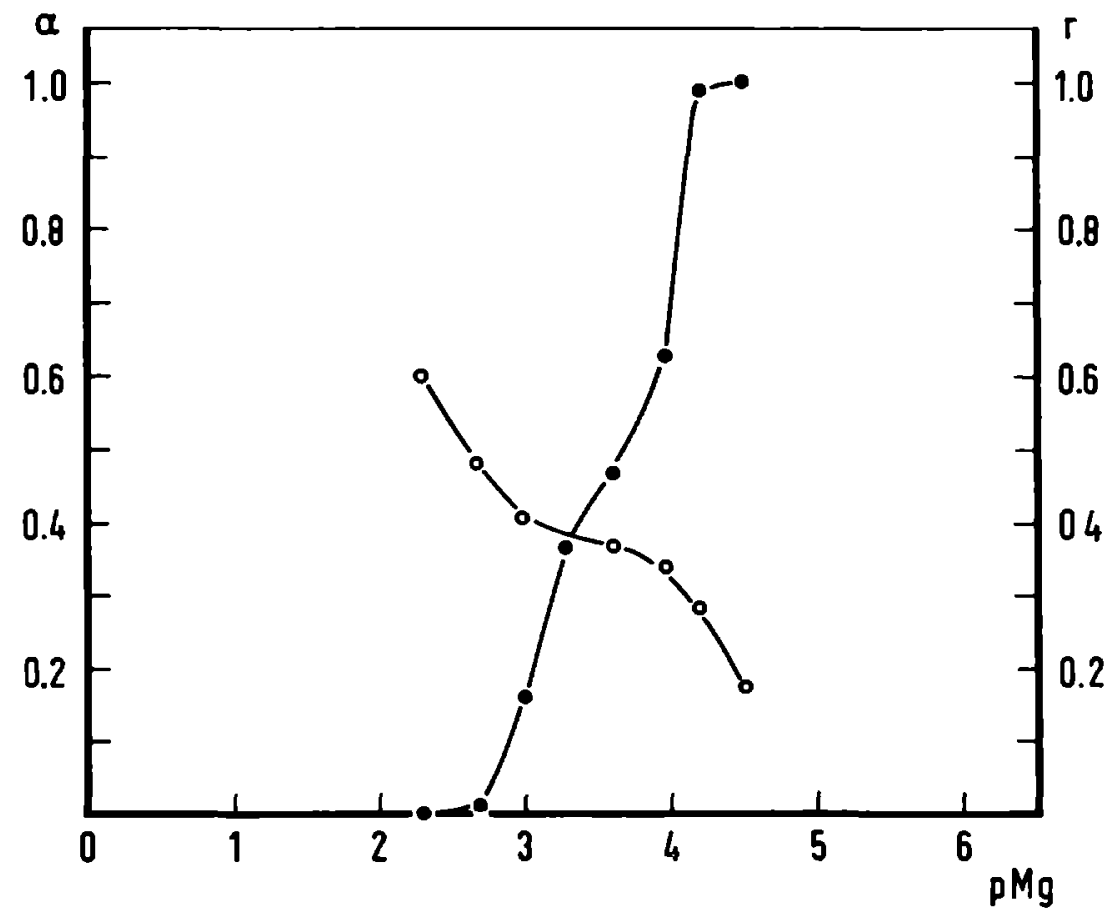

Fig. 2.5. Effect of $\mathrm{pMg}$ on the dissociation of yeast ribosomes and on $\mathrm{Mg}^{++}$-binding to yeast ribosomes in the presence of $10^{-2} \mathrm{M}$ phosphate buffer $(\mathrm{pH}=7.4)$.

- degree of dissociation ( $\alpha$ ).

- equivalents of bound magnesium per ribosomal phosphate (r).

zero at $\mathrm{pH}=7.4$. In fig. $2.6, \alpha$ is plotted versus $\mathrm{Z}$. The curves so obtained practically coincide. The differences observed must be attributed to small variations in the ribosome preparations, as was found from duplicate experiments on different ribosome preparations. So, within the limits of experimental accuracy $\alpha$ is found to be a simple function of $r$ and thus of $Z=1-$ r. To decide whether the amount of bound magnesium ions or $Z$ is the limiting factor, the charge of the ribosomes has to be changed in a different way. This can simply be attained by changing the $\mathrm{pH}$. In the range of $\mathrm{pH}=$ 6.0 to 9.5 there are no ionized groups on the ribosomal RNA, except the primary phosphate groups, which bear no hydrogen ions within this 


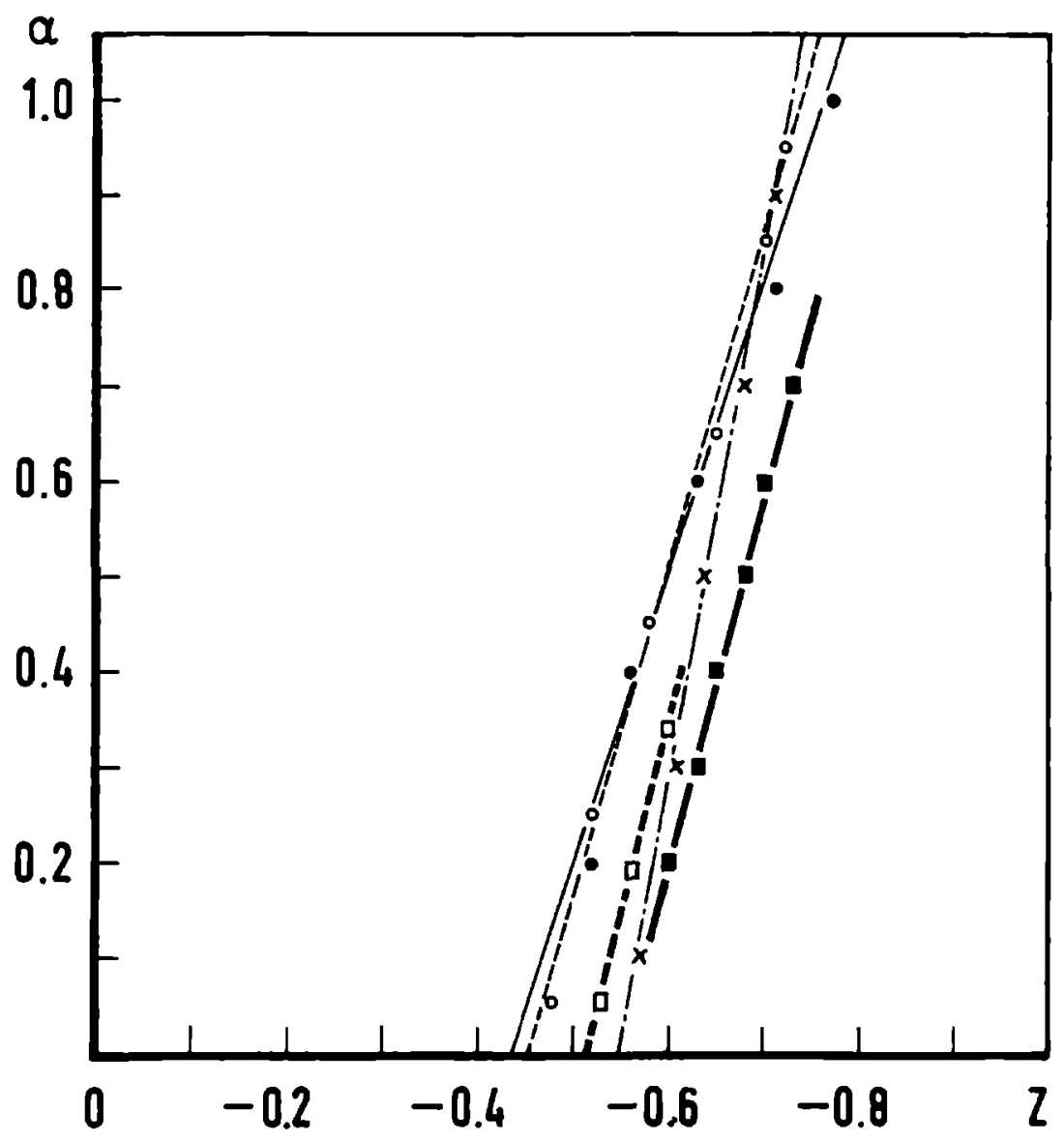

Fig.2.6. The degree of dissociation ( $\alpha$ ) as a function of the electrical charge (Z) of yeast ribosomes.

- - - - read from figure 2

$-0-0 \_\quad$ read from figure 3

$-X-X-X-\quad$ read from figure 4

- . - a. . read from figure $6+7$

- ०- ०- - - measured with $\mathrm{r}=0.46$

For details see text. 
$\mathrm{pH}-$ range ${ }^{28}$. Hence, changing the $\mathrm{pH}$ within the range of 6.0 to 9.5 only alters the charge of the ribosomal proteins. So for our study we need to know the proton charge of the ribosomal proteins as a function of the $\mathrm{pH}$. We estimated this by hydrogen ion titrations. For a direct comparison with the results of the experiments described above the charge of the ribosomal proteins was again chosen zero at $\mathrm{pH}=7.4$. Fig. 2.7 shows the result of such a titration. At about $\mathrm{pH}=7.5$ an inflection point is found. In fig. 2.8 both $\alpha$ and I are

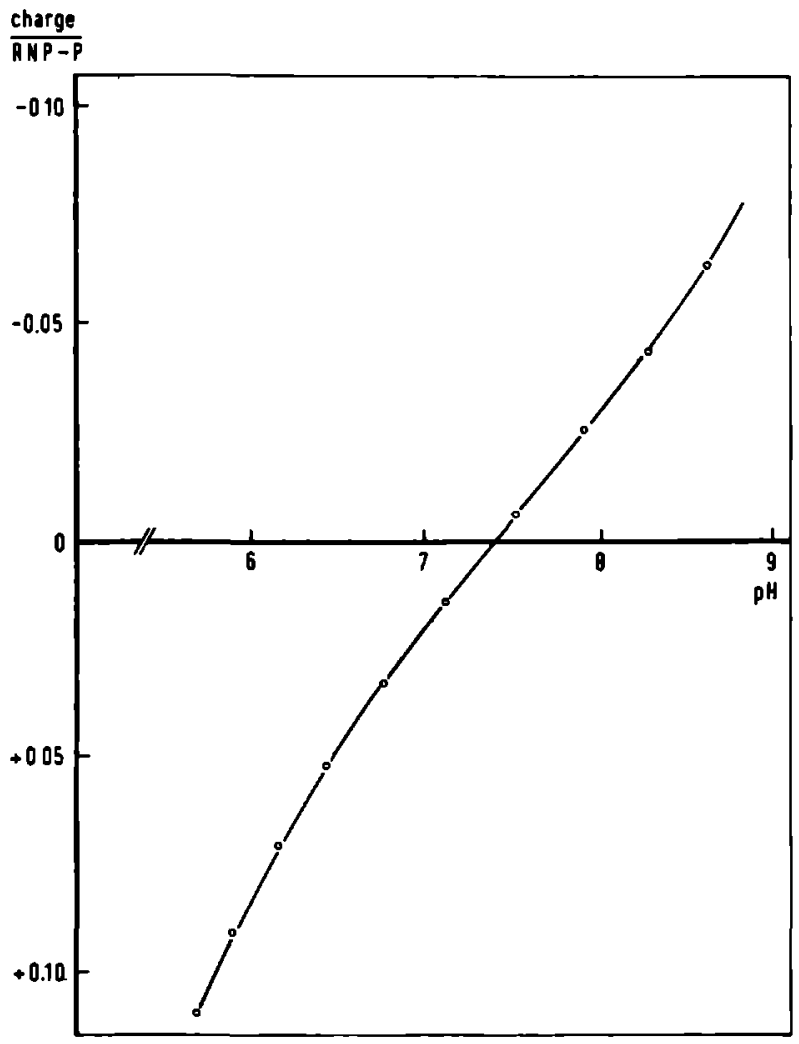

Fig. 2.7. Effect of $\mathrm{pH}$ on the electrical charge of ribosomal proteins in intact yeast ribosomes, expressed in equivalents per ribosomal phosphate. The charge of ribosomal proteins is chosen zero at $\mathbf{p H}=7.4$. 
plotted versus $\mathrm{pH}$. In these measurements the magnesium and potassium concentration were held constant instead of the ionic strength. The dissociation curve also has an inflection point at about $\mathrm{pH}=7.5$. At each $\mathrm{pH}$ the charge of the ribosomal proteins and $\mathrm{r}$ are known. Hence we can plot again $\alpha$ versus $Z$. The results are also shown in fig. 2.6. In this figure a similar curve is shown at $r=0.46$. A number of other curves, at various values of $r$ were measured, all being well in agreement with the curves given in fig.2.6. These are not inserted to avoid overcrowding of the figure. This result strongly suggests that $\alpha$ only depends on the total charge, it being irrelevant whether this charge is located on the RNA chains or on the proteins. As is seen in fig. 2.8 the dissociation increases with increasing $\mathrm{pH}$. We have also studied the reversibility of this reaction. Association by merely decreasing the $\mathrm{pH}$ could however not be obtained. This is not surprising in connection with the hysteresis as indicated in fig. 2.3, from which it can be seen that association takes place at about $\mathrm{pMg}=3.15$, corresponding to about $\mathrm{Z}(=\mathrm{r}-1)=-0.40$. A decrease of the $\mathrm{pH}$ from 8.3 to 6.6 (further decrease causes a decomposition of the ribosomes) causes a change of the total charge from about -0.70 to -0.60 , which is insufficient to obtain an association. For this reason the $\mathrm{pMg}$ was first increased to 3.15 at $\mathrm{pH}=8.3$. As expected no association was obtained, but subsequent changing the $\mathrm{pH}$ from 8.3 tot 6.6 with a constant value of $\mathrm{r}$ (0.59) indeed caused association. This is another indication that the dissociation and association are controlled by the charge of the ribosomes.*)

Finally, we have compared the effect of magnesium, calcium, strontium and barium ions. For this study the phosphate buffer could not be used and was replaced by $0.01 \mathrm{M}$. trisbuffer. All ribosome solutions contained divalent cation concentrations of $2 \times 10^{-3} \mathrm{M}$. In the case of magnesium and calcium ions only the $80 \mathrm{~S}$ component was found, while strontium and barium ions showed a different behaviour. Ultracentrifuge recordings which illustrate this effect are given in figs. 2.9 and 2.10. In the case of strontium ions three peaks

*) Note: In recent experiments, which could not yet be incorporated in this thesis, we have investigated the degree of dissociation in association experiments as a function of the amount of bound magnesium ions. It appears that the degree of dissociation is again a function of the charge. The total association reaction takes place within a $\Delta$ Z-range of about 0.05 at about $\mathrm{r}=\mathbf{0 . 6 0}$. 


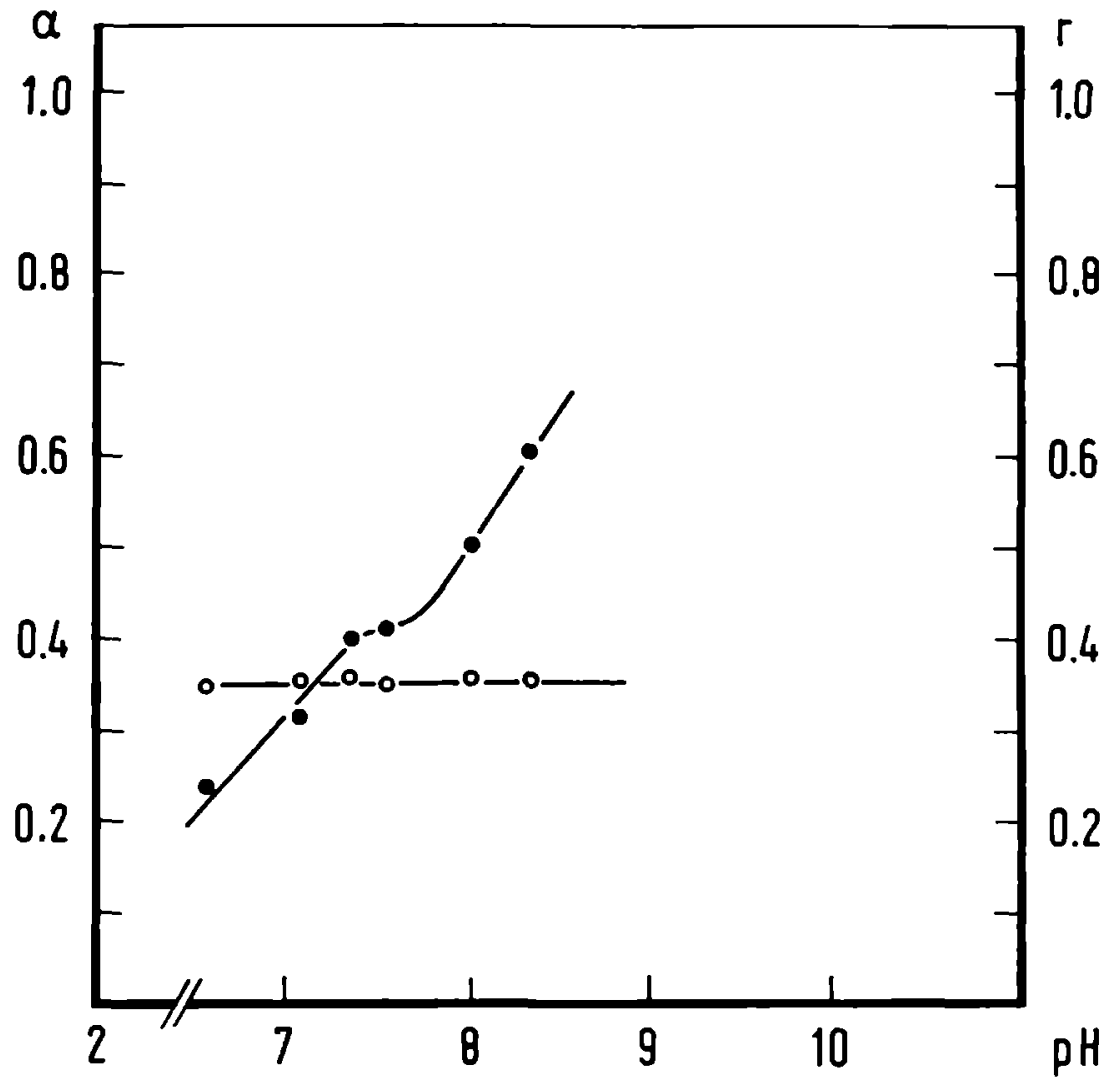

Fig.2.8. Effect of $\mathrm{pH}$ on the dissociation of yeast ribosomes and on $\mathrm{Mg}^{++}$binding to yeast ribosomes.

- degree of dissociation $(\alpha)$

equivalents of bound magnesium per ribosomal phosphate (r)

are detectable, showing a dissociation, but from a comparison with fig. 2.11, which shows the normal dissociation behaviour with symmetrical peaks (in phosphate buffer at low magnesium ion concentration) it is seen that a normal picture is not obtained. In the case of barium ions still greater deviations were found.

As already shown the dissociation reaction is not a real equilibrium reaction. This might be caused by structural changes, accompanying the dissociation of ribosomes, or by irreversible binding of magnesium ions. However, we have checked this binding and found complete reversibility. More- 


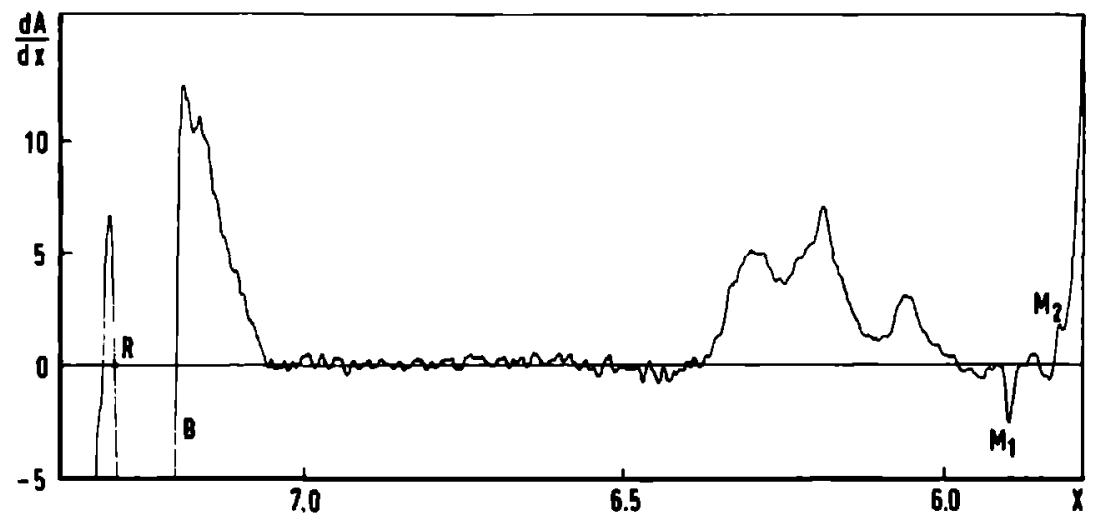

Fig.2.9. Scan of the first derivative of the absorbance $d A / d x$ versus $x$, obtained with yeast ribosomes in $10^{-2} \mathrm{M}$ Trisbuffer ( $\mathrm{pH}=7.4$ ) and $2 \times 10^{-3} \mathrm{M} \mathrm{SrCl}_{2}$.

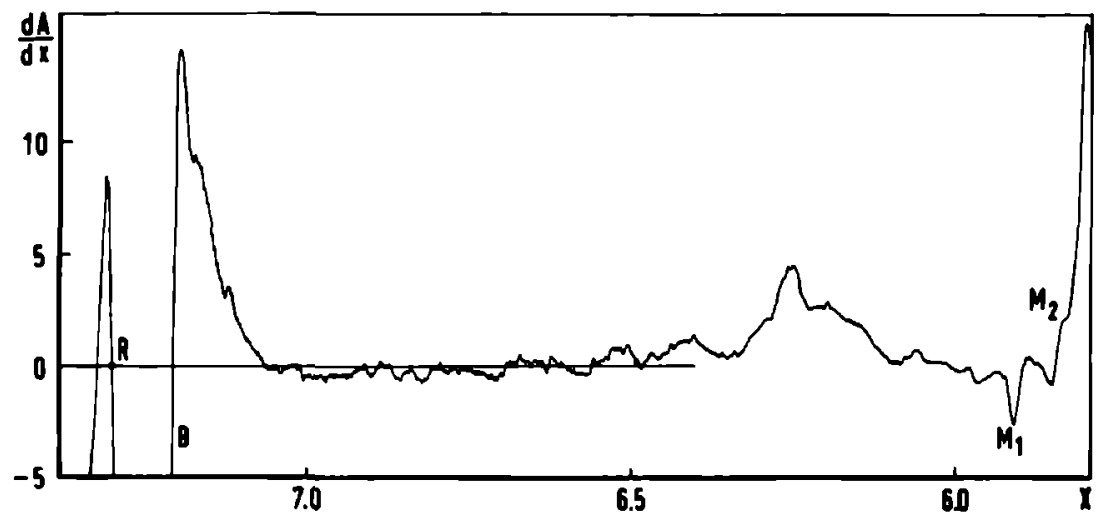

Fig. 2.10. Scan of $\mathrm{dA} / \mathrm{dx}$ versus $\mathrm{x}$, obtained with yeast nibosomes in $10^{-2} \mathrm{M}$ Trisbuffer (pH $=7.4)$ and $2 \times 10^{-3} \mathrm{M} \mathrm{BaCl}_{2}$. 


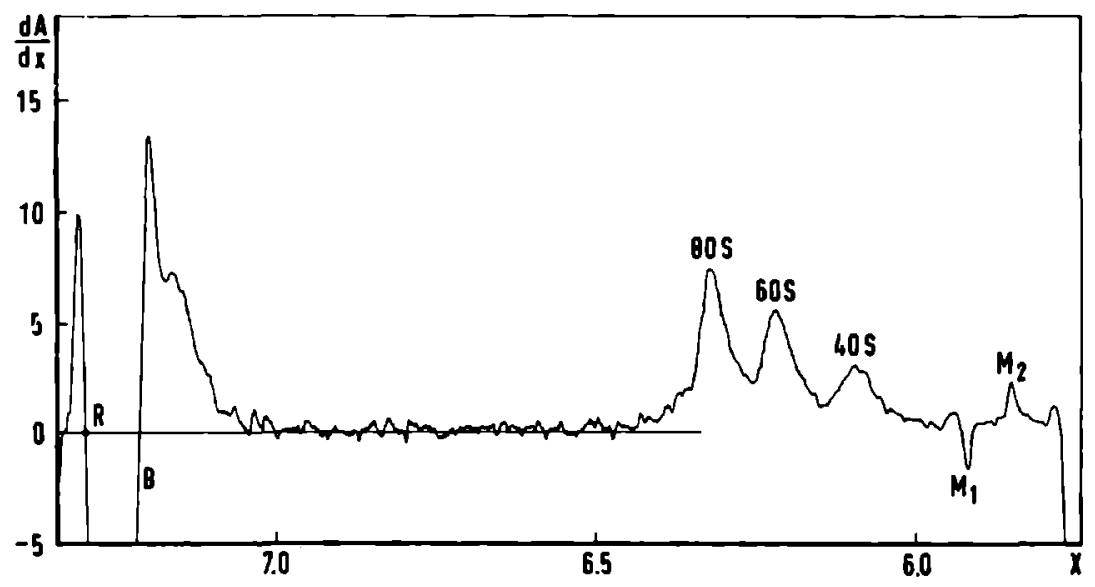

Fig 2.11. Scan of $\mathrm{dA} / \mathrm{dx}$ versus $\mathrm{x}$, obtained with yeast ribosomes in $2 \times 10^{-3} \mathrm{M}$ phosphate-buffer ( $\mathrm{pH}=7.4$ ) and low magnesium ion concentration.

over, by means of measurements of the optical rotatory dispersion and circular dichroism between 225 and $350 \mathrm{~m} \mu$ no differences could be detected between the $80 S$-particle and a mixture of the ribosomal subunits (fig. 2.12). In addition, no hypochromicity at $258 \mathrm{~m} \mu$ as a function of bound magnesium ions was found. Evidently the dissociation and association reactions are not accompanied by an alteration in the secondary structure. Changes in the tertiary structure, however, can not be detected by these methods. On treatment of yeast ribosomes with EDTA an expanded particle is formed, as is found from measurements of the sedimentation coefficient, but no change in the optical rotatory dispersion was observed 29 . However, in the experimental conditions used in the author's investigation, the sedimentation coefficients at zero concentration appeared to be constant, being $79.9 \mathrm{~S}, 59.1 \mathrm{~S}$ and $38.2 \mathrm{~S}$ for the complete ribosome and the ribosomal subunits respectively, indicating that no alterations in the tertiary structure occurred. Hence, it seems justified to state that the hysteresis is neither caused by structural changes, accompanying the dissociation or association reactions, nor by irreversible binding of magnesium ions. 

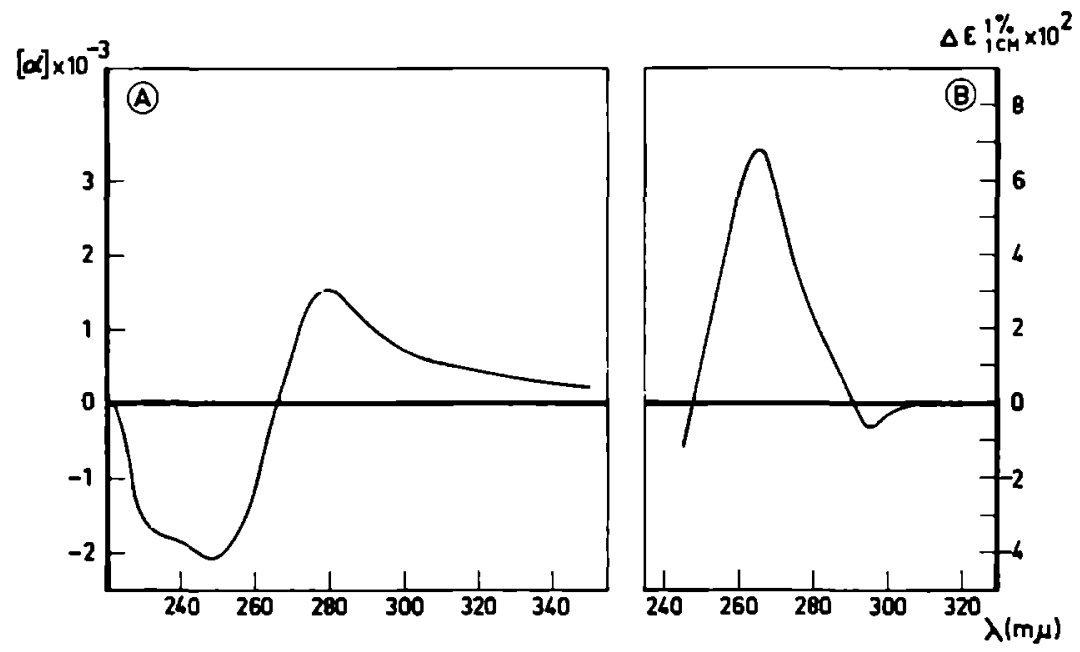

Fig. 2.12. O.R.D. spectrum (A) and C.D. spectrum (B) of yeast ribosomes. The curves hold both for the 80S-particle and a mixture of the ribosomal subunits. $([\alpha]=$ specific rotation; $\Delta E=$ the difference in extinction between left and right circularly-polarised light).

\subsection{Discussion}

A number of the results and statements of the previous section require a discussion in more detail.

\subsubsection{Dissociation-association and charge}

\subsubsection{The effect of monovalent cations}

From the plots of $\mathrm{r}$ versus $\mathrm{pMg}$ in figs. $2.3,2.4$, and 2.5 it is seen that the ionic strength has a marked effect on bound magnesium. Nevertheless the charge of the ribosomes at $\mathrm{pH}=7.4$ was calculated from $\mathrm{Z}=1-\mathrm{r}$. In fact this means that we suppose that potassium ions are not bound. Goldberg 30 found that his results of a study of magnesium binding by E.coli ribosomes were in agreement with the idea of Felsenfeld ${ }^{31}$, that the interaction of bivalent cations with polynucleotides is a "strong interaction" or "site binding" and that of monovalent ions a weak or "non-specific interaction". Choi and $\mathrm{Carr}^{32}$ claimed a weaker binding for monovalent cations than for bivalent cations, though both were considered as a non-specific interaction. In our 
opinion the interpretation of Goldberg has to be preferred, especially since our experimental and theoretical analyses of the binding of magnesium ions to yeast ribosomes show, that the effect of monovalent cations - except hydrogen ions - on bound magnesium can be explained as a pure ionic strength effect. Chapter III will deal with this problem in more detail.

The contribution of the charge of the ribosomal proteins to the total charge was found from hydrogen ion titrations. For all calculations we used fig. 2.7, which is justified since hydrogen ion titrations showed that the effect of monovalent cations on the charge of the ribosomal proteins is very small. This is not surprising. First hydrogen ions are monovalent while magnesium 1ons are bivalent. Second the contribution of the charge of the ribosomal preceins to the total charge is small in comparison with the contribution of the phosphate groups of the ribosomal RNA. As an example it can be seen from the figs. 2.3 and 2.5 that a change in the concentration of the phosphate buffer from $2 \times 10^{-3} \mathrm{M}$ to $10^{-2} \mathrm{M}$ cause a change in $\mathrm{r}$ from 0.49 to 0.32 at $\mathrm{pMg}=4$. Hence $\mathrm{Z}$ changes from -0.51 to -0.68 , so $33 \%$. From fig. 2.7 it is seen that the contribution of the ribosomal proteins to the total charge is not more than about 0.10 . Even a ionic strength effect of $33 \%$ (and this is much too high since hydrogen ions are monovalent) alters the contribution to the total charge with not more than about 0.033 .

\subsubsection{The effect of divalent cations}

Our conclusion that the dissociation-association reactions are controlled by the charge of the ribosomes includes that all cations which can be bound, must be able to replace magnesium ions. Indeed a number of cations can do so. Magnesium can be replaced by polyamines and divalent cations, such as calcium, zinc, nickel, manganese and cobalt, dependent on the ribosome source. $4,33,34$

However, barium and strontium were ineffective in the reconstitution of 605 and $40 S$ subunits of yeast ribosomes to $80 S$ particles ${ }^{4}$. It was for this reason that we examined the effect of these divalent cations. We found that these cations cause an abnormal behaviour in the ultracentrifuge, indicating that some structural change occurs (figs. 2.9 and 2.10). In our opinion all these results strongly suggest that all cations, which can be bound, including the monovalent hydrogen ion, are able to replace magnesium ions, provided that they do not cause an alteration in the ribosomal structure. 
In all plots, which show $\alpha$ as a function of $\mathrm{pMg}$ or $\mathrm{pH}$ an inflection point is found. In fig. 2.5 this inflection point lies within the same $\mathrm{pMg}$ region as the plateau region of the binding curve. In fig. 2.8 the inflection point is found at about $\mathrm{pH}=7.5$. At this $\mathrm{pH}$ the titration curve presented in fig. 2.7 also shows an inflection point. These results also suggest that $\alpha$ remains constant as long as the charge of the ribosomes does not alter. It is noteworthy that the inflection points in all plots of $\alpha$ vs $\mathrm{pMg}$ are at about $\mathrm{I}=0.40$, suggesting that at this value of $r$ a first endpoint in the binding curve might exist. Indeed, in a more extended study of the binding of magnesium ions to yeast ribosomes this first endpoint could be demonstrated. (see chapter III)

\subsubsection{The hysteresis}

Our experiments indicate that the dissociation-association reaction of yeast ribosomes is not a real equilibrium reaction. This fact has been reported for the first time by Ts'o and Vinograd in rabbit reticoluyte ribosomes ${ }^{35}$. Likewise association of the subunits of E.coli ribosomes only occurs when the magnesium ion concentration is above $3 \times 10^{-3} \mathrm{M}$. (see ref.30) However, in two recent papers of Bielka et al. $^{36}$ and Real Scafati ${ }^{37}$ reversibility is suggested for rat liver and E. coli ribosomes respectively. In fact these authors measured the time-dependence of the dissociation reactions, but since they did not check the reversibility of the reaction by gradual increase of the magnesium ion concentration, their conclusion does not seem justified.

From measurements of the optical rotatory dispersion, circular dichroism and hypochromicity we concluded that the hysteresis is not caused by structural changes, accompanying the dissociation-association reactions. However, Miall and Walker ${ }^{38}$ reported a difference in the circular dichroism for the $70 \mathrm{~S}$ ribosomes of E.coli and their subunits, but others reported results for optical rotatory dispersion in very good agreement with our measurements 29,39 .

Accepting that the dissociation-association reactions are controlled by the charge and that the subunits are not bound together by salt bridges, the question arises which forces are responsible for holding the subunits together. It seems probable that short-range attraction forces, such as hydrogen bonds or hydrophobic interactions, are responsible, since it can easily be shown that short-range attraction forces in combination with electrostatic repulsion forces can explain at least qualitatively the hysteresis mentioned above. In fig. 2.13a two electrostatic repulsion curves for small and large charges ( $a$ and $b$ 


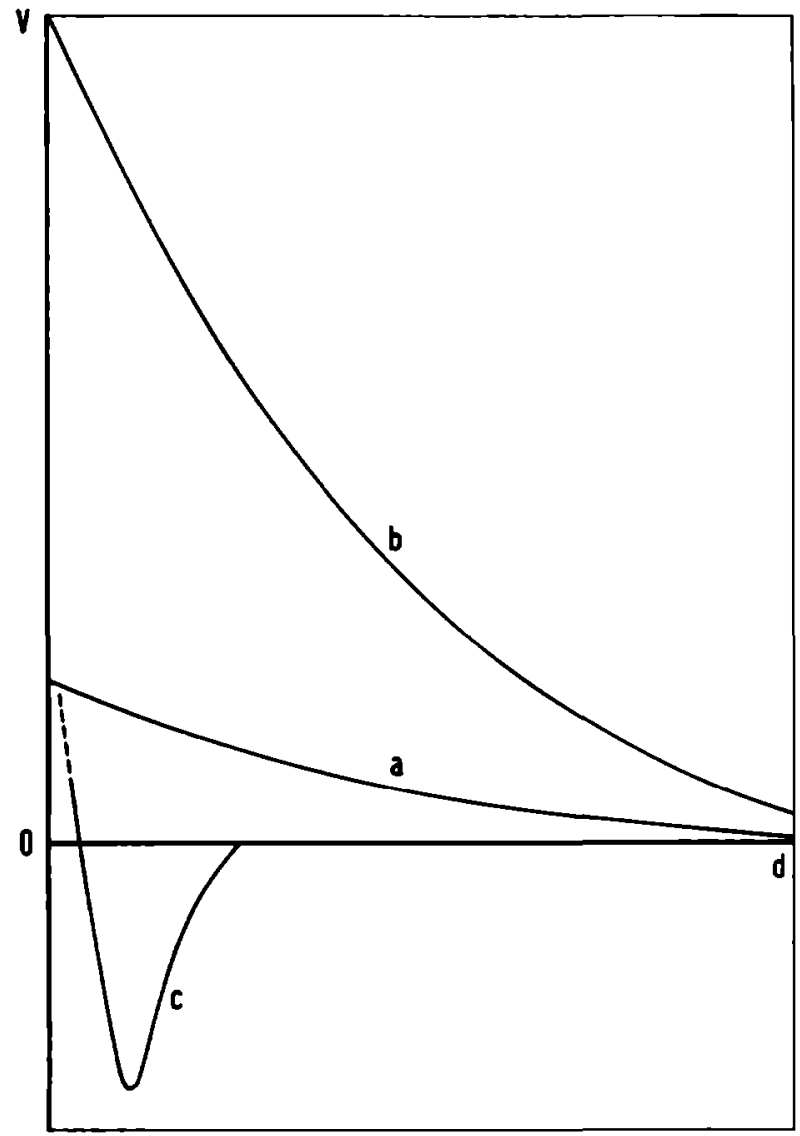

Fig.2.13.a. Plot of energy of interaction versus the distance $d$ between the surfaces of two particles.

$a=$ repulsion curve for small charges

$b=$ repulsion curve for large charges

$c=$ attraction curve for short-range forces 


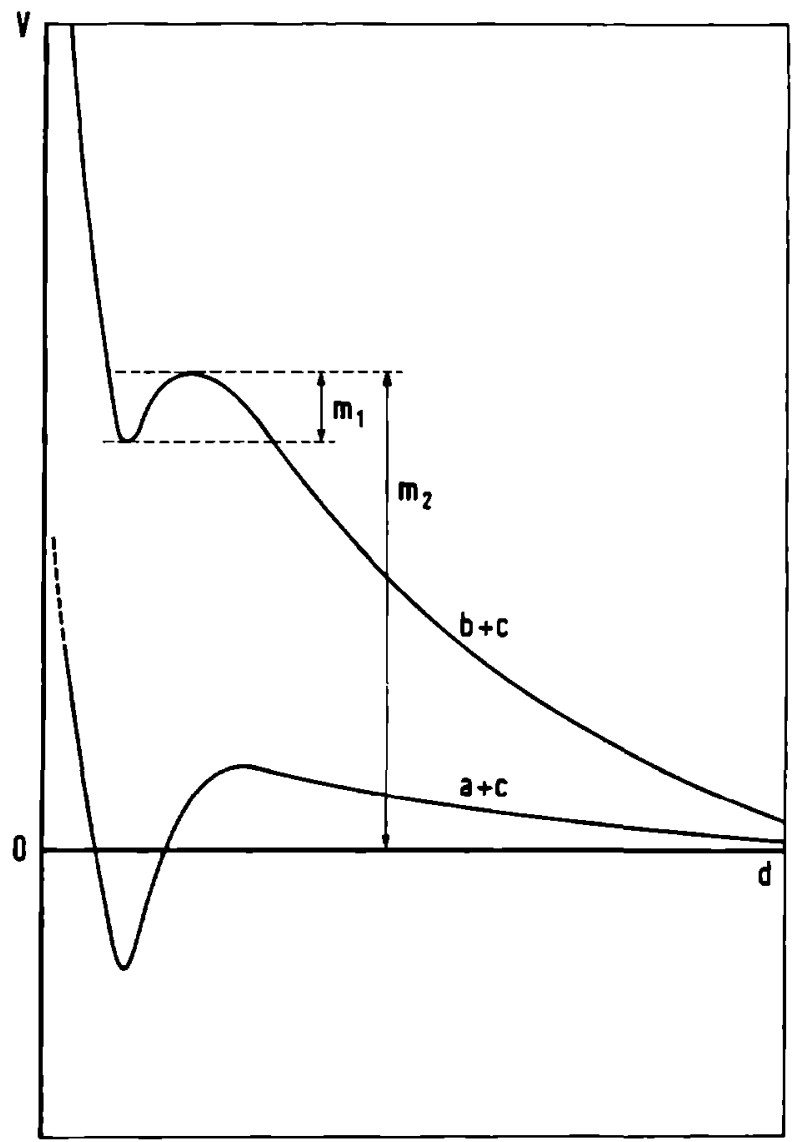

Fig.2.13.b. Total energy of interaction versus distance d.

$a+c=$ the sum of curves $a$ and $c$ of figure 2.13.a.

$b+c=$ the sum of curves $b$ and $c$ of figure 2.13.a. 
resp.), and an attraction curve for short-range forces, c, are plotted as a function of the distance between the surfaces of the two particles. The sum of $a$ and $c$, and of $b$ and $c$ gives the total potential energy of interaction for small and large charges respectively (fig. 2.13b). The possibility of the $80 \mathrm{~S}$ particles to dissociate is determined by the height of $m_{1}$. If this height is a few times $\mathrm{kT}$, dissociation is possible. Since $\mathrm{m}_{2}$ is much larger than $\mathrm{m}_{1}$, association can not take place.Curve $(\mathrm{a}+\mathrm{c})$ in fig. $2.13 \mathrm{~b}$ shows the situation in which association is possible, but dissociation can not take place. In the situation given by curve $(b+c)$ there is a much higher repulsion than in the situation of curve $(a+c)$. So hysteresis in the association-dissociation can exist. The situation is comparable with that of the repeptization phenomena of colloids 40 .

From fig. 2.6 it is seen that the effect of the ionic strength, at a given charge, seems to be negligible. Indeedthe effect of the ionic strength is relatively small at the very short distances, where short-range forces act. (see also Oosawa $^{41}$ )

\subsubsection{Heterogeneity}

A similar kind of heterogeneity as we described has been mentioned by Ts'o and Vinograd ${ }^{35}$. At the moment the cause of this heterogeneity is not clear. There are several possibilities. Messenger RNA or transfer RNA may be associated with some ribosomes and consequently the ribosomes might have a different charge. It is also possible that the ribosomal RNA is heterogeneous. This is supported by the results of Yankofsky and Spiegelman ${ }^{42}$, Michelson and Suyama ${ }^{43}$, and Young 44 , who showed heterogeneity in the ribosomal RNA of bacillus megaterium, neurosphora crassa and E.coli respectively. Finally the composition of the ribosomal proteins may be different for different classes of ribosomes. It will require much more work to elucidate this problem.

\subsubsection{The possible existence of a dissociation factor}

From the data presented it will be clear that the dissociation and the association reactions require rather large differences in ionic conditions. It seems very unlikely that such differences can occur in the living cell. If this is true, the dissociation-association reaction in the living cell has to be regulated in an other way. It is known that in the living cell of E.coli a constant pool of 
ribosomal subunits exists, ${ }^{45}$ suggesting that the dissociation of E.coli ribosomes is caused by complexing with a dissociation factor. The constant pool of subunits would be maintained by the limited quantity of the dissociation factor. Subrumanian, Ron and Davis ${ }^{46}$ succeeded in isolating this factor. Since the dissociation and association in the living cells of yeast can hardly be caused by such large variations in the ionic conditions as found in our experiments, we suppose that also in yeast cells a dissociation factor occurs. A more general occurrence of a dissociation factor would also explain the finding of Bishop 47 , that after the removal of the blocking reagents puromycin or $\mathrm{NaF}$ from rabbit reticulocytes, polysomes are formed again, accompanied by a decrease of the amount of $80 \mathrm{~S}$-particles, while the number of subunits remains constant. 
References

1. M.Nomura, C.V. Lowry and C. Guthrie, Proc. Natl. Acad. Sci. U.S., 58 (1967) 1487.

2. C. Guthrie and M. Nomura, Nature, 219 (1968) 232.

3. B. Colombo, C. Vesco and C. Baglioni, Proc. Natl. Acad. Sci. U.S.,61 (1968) 651 .

4. M.L. Petermann, The Physical and Chemical Properties of Ribosomes, Elsevier, Amsterdam, 1964.

5. A.G.W.J. Lansink, Thesis, University of Nijmegen, The Netherlands, 1964.

6. G. Zubay, Biochim. Biophys. Acta, 32 (1959) 233.

7. A.M. Willemsen, Thesis, University of Nijmegen, the Netherlands, 1969.

8. J.D. Watson, Bull. Soc. Chim. Biol., 46 (1964) 1399.

9. M.L. Petermann and A. Pavlovec, Biopolymers, 7 (1969) 73.

10. M.L. Petermann and A. Pavlovec, Biochemistry, 6 (1967) 2950.

11. F. Miyazawa and T. Tamaoki, Biochim. Biophys. Acta, 134 (1967) 470.

12. T. Tamaoki and F. Miyazawa, J. Mol. Biol., 17 (1966) 537.

13. R.S. Morgan, C. Greenspan and B. Cunningham, Biochim. Biophys. Acta, 68 (1963) 642.

14. R. Zak, K.G. Nair and M. Rabinowitz, Nature 210 (1966) 169.

15. T. Tamaoki and F. Miyazawa, J. Mol. Biol., 23 (1967) 35.

16. F. Miyazawa and T. Tamaoki, J. Mol. Biol., 24 (1967) 485.

17. J.H. Parish, P.A. Fletcher and M Brown, Biochem. J., 110 (1968) 39P

18. M.L. Petermann and A. Pavlovec, Biophys. J., 8 (1968) A-181.

19. F. Miyazawa, V.C. Dick and T. Tamaoki, Biochim. Biophys. Acta, 155 (1968) 193.

20. B.F. Vanyushin and D.B. Dunn, Biochim. Biophys. Acta, 134 (1967) 91 .

21. K. Nakamura and T. Tamaoki, Biochim. Biophys. Acta, 161 (1968) 368.

22. F.C. Chao and H.K. Schachman, Arch. Biochem. Biophys., 61 (1956) 220.

23. A.I. Aronson and B.J. McCarthy, Biophys. J., 1 (1961) 215.

24. C.H. Fiske and Y. Subbarow, J. Biol. Chem., 81 (1929) 629.

25. W.L. van Es and W.S. Bont, Anal. Biochem., 17 (1966) 327.

26. S.H. de Bruin and G.A.J. van Os, Rec. Trav. Chim., 87 (1968) 861.

27. H.K. Schachman, Ultracentrifugation in Biochemistry, New York: Academic Press, 1959. 
28. R.A. Cox and U.Z. Littauer, Biochim. Biophys. Acta, 72 (1963) 188.

29. P. McPhie and W.B. Gratzer, Biochemistry 5 (1966) 1310.

30. A. Goldberg, J. Mol. Biol., 15 (1966) 663.

31. G. Felsenfeld. In: The Molecular Basis of Neoplasia. Austin: University of Texas Press (1962).

32. Y.S. Choi and C.W. Carr, J.Mol. Biol., 25 (1967) 331.

33. M. Tal, Biochim. Biophys. Acta, 169 (1968) 564.

34. R.Roskoski, Arch. Biochem. Biophys., 130 (1969) 561.

35. P.O.P. Ts'o and J. Vinograd, Biochim. Biophys. Acta, 49 (1961) 113.

36. H. Bielka, H. Welfle, M. Böttger and W. Förster, European J. Biochem., 5 (1968) 183.

37. L. Danusso and A. Reale Scafati, Ann. Ist. Super. Sanita 4 (1968) 267.

38. S.H. Miall and I.O. Walker, Biochim. Biophys. Acta, 166 (1968) 711.

39. P.K. Sarkar, J.T. Yang and P. Doty, Biopolymers 5 (1967) 1.

40. E.J.W. Verwey and J.Th.G. Overbeek, Theory of the Stability of Lyophobic Colloids, Elsevier, Amsterdam, 1948.

41. F. Oosawa, Biopolymers 6 (1968) 1633.

42. S.A. Yankofsky and S. Spiegelman, Proc. Natl. Acad. Sci. U.S., 43 (1963) 538.

43. E.L. Michelson and Y. Suyama, Biochim. Biophys. Acta, 157 (1968) 200.

44. R.J. Young, Biochemistry, 7 (1968) 2263.

45. R.E. Köhler, E.Z. Ron and B.D. Davis, J.Mol. Biol., 36 (1968) 71.

46. A.R. Subrumanian, E.Z. Ron and B.D. Davis, Proc. Natl. Acad. Sci. U.S., 61 (1968) 761.

47. J.O. Bishop, Arch. Biochem. Biophys. 125 (1968) 449. 



\section{CHAPTER III}

\section{MAGNESIUM BINDING TO YEAST RIBOSOMES}

\subsection{Introduction}

In Chapter II two suppositions with regard to the binding of magnesium ions by yeast ribosomes were made. First it was proposed that the electrical charge of the ribosomes can be calculated from $Z=1-r$, based on the assumption that monovalent cations are not bound at all. This would mean that the effect of monovalent cations can be explained as a ionic strength effect. Second it was suggested that there are two classes of binding sites. Hence a more detailed study of the binding of magnesium ions to check the correctness of these suppositions seemed desirable.

In the literature only a few reports have been given on this binding ${ }^{1-3}$. It has been found that the ionic strength has a marked effect on the amount of bound magnesium ions. At low ionic strength magnesium ions are bound very tightly. At high ionic strength the binding is much less tight. These results have been interpreted both as a ionic strength effect 2 and as a competitive effect. ${ }^{3}$ Finally it has been reported that the magnesium binding is affected by the $\mathrm{pH}$. An increase of the $\mathrm{pH}$ results in a decrease of the amount of bound magnesium ions 1,2 .

So far the available experimental data have been treated only qualitatively. In the present chapter an attempt will be made to treat the experimental data in a quantitative way, in terms of classes of binding sites, dissociation constants and ionic strength effect. First the theoretical aspects will be given, followed by the experimental results. Finally the experimental results will be discussed in the light of the theoretical considerations.

\subsection{Materials and methods}

Materials and methods were the same as described in chapter II. In all binding experiments the concentration of ribosomes was about $10 \mathrm{mg} / \mathrm{ml}$. If desired, the ionic strength was held constant by adding $\mathrm{K}_{2} \mathrm{SO}_{4}$ when $\mathrm{MgSO}_{4}$ was removed.

Activities were calculated according to the Debye-Hückel approximation. Calculations of the binding curves were executed on the computer IBM system 360/50 using a Fortran IV program. 


\subsection{Theoretical aspects}

When there is a reversible interaction between a macro-ion and small ions, e.g. magnesium ions, the simplest situation is the one in which all hinding sites are identical and completely independent. In this case the relation between the fraction $\beta$ of dissociated groups and the $\mathrm{pMg}$ is given by:

$$
\mathrm{pMg}=\mathrm{pK}+\log \frac{\beta}{1-\beta}
$$

with $\mathrm{pMg}=-\log \left[\mathrm{Mg}^{++}\right]$and $\mathrm{pK}=-\log \mathrm{K}$, where $\mathrm{K}$ is the dissociation constant. However, generally the identical binding sites interact with one another in such a way that binding at any site affects the binding affinity at all other sites. This phenomenon has to be a attributed to the fact that the work required to dissociate a small ion from a macro-ion is a function of the charges located on the macro-ion. According to the theory of LinderstromLang $^{4}$ this effect results in an extra term in equation (1), which then becomes:

$$
\mathrm{pMg}=\mathrm{pK}_{\text {int }, \mathrm{Mg}}+\log \frac{\beta}{1-\beta}-0.868 \mathrm{wz}_{i} \mathrm{Z}
$$

with $\mathrm{Z}=$ the total charge of the macro-ion; $\mathrm{z}_{\mathrm{i}}=$ the charge of the small ion; $\mathrm{K}_{\text {int } \mathrm{Mg}}=$ intrinsic dissociation constant, i.e. the dissociation constant when the charge of the macro-ion is zero. $w$ is the so called electrostatic interaction factor and the term $-0.868 \mathrm{wz}_{\mathrm{i}} \mathrm{Z}$ can be considered as a measure for the extra work required to dissociate a small ion from a macro-ion because of its charge $Z$. This term accounts for the effect of the ionic strength on the interaction between charges located on the macro-ion.

It should be noted that the Linderstrom-Lang approach is an approximation because the electrostatic interaction is considered as an effect of the total charge $\mathrm{Z}$, and not as the resultant of the interactions of the individual charges on the macromolecule. It is clear that $\mathrm{w}$ will be strongly dependent on the model chosen to represent the macro-ion, but calculations show that $w$ is a constant for a chosen model as long as the temperature, ionic strength and conformation are constant. The latter condition, constant conformation, is not satisfied in our binding experiments, since at low magnesium ion concentration ribosomes dissociate into two subunits. To investigate the effect of the dissociation on $\mathbf{w}$ we have made some approximate calculations. For these 


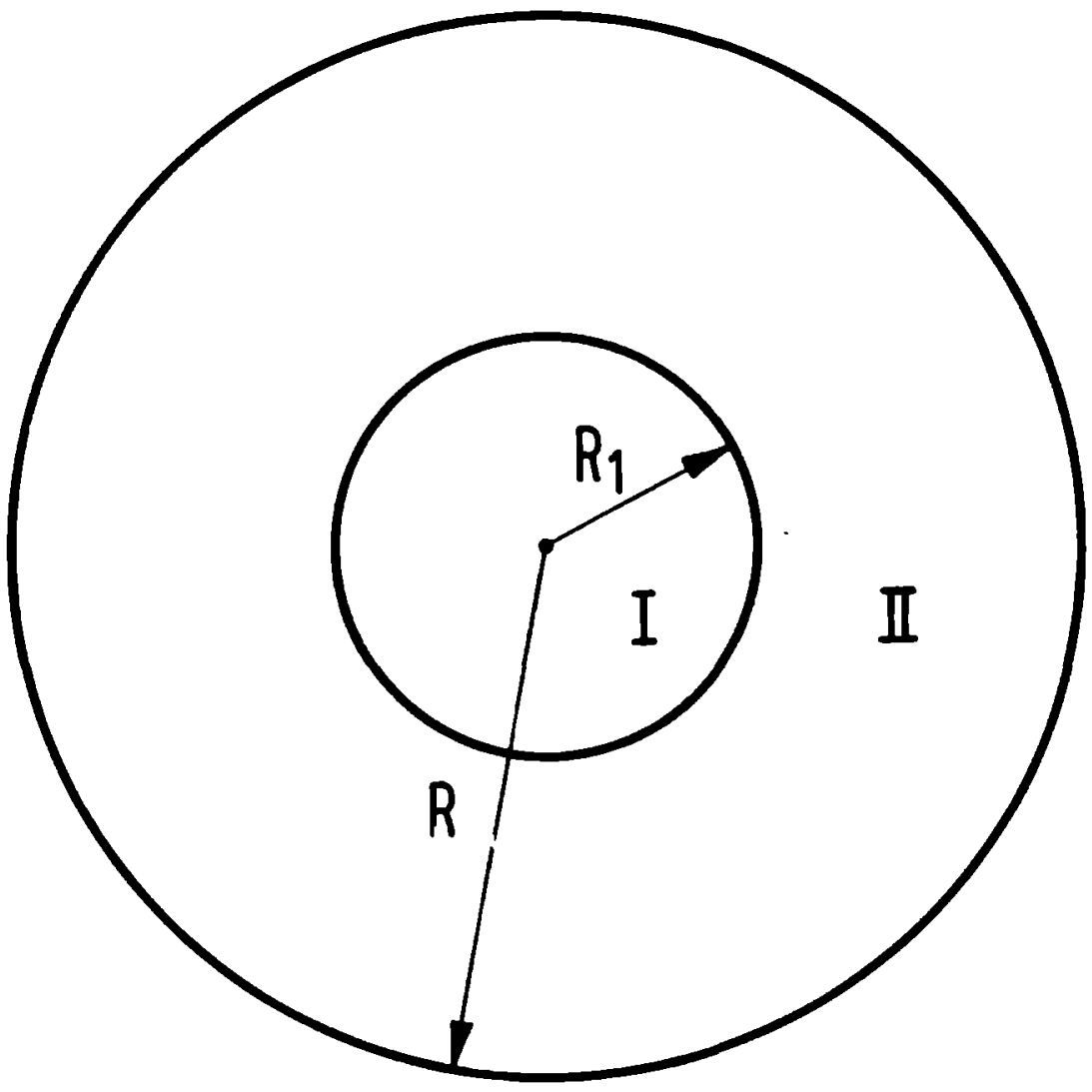

Fig.3.1. Schematic model for solvent permeable macro-ion.

Region I with radius $R_{1}$ is impenetrable to solvent.

Region II consists of macro-ion substance and solvent.

$\mathbf{R}=$ radius of hydrated particle.

calculations the spherical model, represented in fig. 3.1, was used. It consists of a central core regarded as impene trable to solvent (region I), surrounded by a shell permitting penetration of solvent (region II), including small ions. In this shell a uniform charge density $\rho$ is assumed. For such a model w car. be calculated from the Debye-Hückel theory as has been done by Tanford ${ }^{5}$. It is found that: 


$$
\begin{aligned}
& w=\frac{9 \epsilon^{2}}{2 \kappa^{2} D\left(R^{3}-R_{0}^{3}\right) k T} \times \\
& \left.\qquad \frac{1}{3}+\frac{1+\kappa R}{\kappa^{3}\left(R^{3}-R_{0}^{3}\right)} \cdot \frac{(1-\gamma \kappa R) \frac{1+\gamma \kappa R_{1}}{1-\gamma \kappa R_{1}} e^{2 \gamma \kappa\left(R-R_{1}\right)}-(1+\gamma \kappa R)}{(1+\gamma) \frac{1+\gamma \kappa R_{1}}{1-\gamma \kappa R_{1}} e^{2 \gamma \kappa\left(R-R_{1}\right)}-(1-\gamma)}\right\}
\end{aligned}
$$

with: $\epsilon=$ proton charge; $\kappa=$ Debye-Hückel parameter; $\mathrm{D}=$ dielectric constant of the solvent; $R=$ radius of the hydrated macro-ion; $R_{0}=$ radius of a compactly folded impenetrable macro-ion, containing the same amount of macromolecular material as the original particle; $k=$ Boltzmann's constant; $T$ $=$ abs. temperature; $R_{1}=$ radius of a central core regarded as impenetrable to solvent; $\boldsymbol{\gamma}^{2}=$ fraction of the volume of the hydrated macro-ion accessible to small ions.

From the definition of $\gamma^{2}$ it follows that:

$$
\gamma^{2}=\frac{R^{3}-R_{0}^{3}}{R^{3}-R_{1}^{3}}
$$

For our purposes the model can be simplified because in view of the present knowledge of the ribosomal structure (see chapter I) there is no reason to believe that ribosomes have an impenetrable core. In addition, for highly hydrated particles like ribosomes probably all but a very small fraction of the macro-ion will be accessible to mobile ions. As a consequense $R_{1}$ and $\gamma^{2}$ can be chosen zero and one respectively. With these values it follows from equation (4) that $R^{3}-R_{n}^{3}=R^{3}$, i.e. $R_{o}^{3}$ can be neglected. Substituting $\gamma=1, R_{1}$ $=0$ and neglecting $R_{0}^{3}$ in equation (3) we get:

$$
\begin{aligned}
& w=\frac{9 \epsilon^{2}}{2 \kappa^{2} D k T R^{3}} \times \\
& \left\{\frac{1}{3}+\frac{1+\kappa R}{\kappa^{3} R^{3}} \cdot \frac{(1-\kappa R) e^{2 k R}-(1+\kappa R)}{2 e^{2 \kappa R}}\right\}
\end{aligned}
$$




\begin{tabular}{|c|c|c|}
\hline $\mathrm{R}(\mathrm{in} \AA)$ & $\mathrm{w} \times 10^{5}$ & $4 / 3 \pi \mathrm{R}^{3} \mathrm{w} \times 10^{21}$ \\
\hline 50 & 1609 & 8.42 \\
75 & 605 & 10.69 \\
100 & 287 & 12.03 \\
125 & 157 & 12.87 \\
150 & 95 & 13.46 \\
175 & 62 & 13.86 \\
\hline
\end{tabular}

Table 3.1. Calculated values of $w$ and $4 / 3 \pi R^{3} w$ as a function of $R$ according to equation (5). Numerical values: $\epsilon=4.77 \times 10^{-10} ; \kappa=5.33 \times 10^{6}$ (corresponding with an ionic strength of 0.025$) ; D=80 ; \mathrm{k}=1.37 \times 10^{-16} ; \mathrm{T}=278^{\circ}$.

Table 3.1 shows values of $w$ as a function of $R$, calculated according to equation (5). It is seen from this table that $w$ strongly depends on the radius of the macro-ion. Since the radii of the subunits are smaller than those of the $80 \mathrm{~S}$ particle $w$ becomes larger on dissociation. However, the effect on $-0.868 \mathrm{wz}_{\mathrm{i}} \mathrm{Z}$ is at least partially compensated by a decrease of the charge $Z$, accompanying the dissociation. In equation (2) $Z$ can be replaced by $4 / 3 \pi R^{3} \rho$. The quantity $\rho$ is independent of the dissociation and association reactions. The third column of table 3.1 shows the calculated values of $4 / 3 \pi R^{3} w$. The radius of the $80 \mathrm{~S}$ particle is about $155 \AA$ Using the known mol. weight ratio of the ribosomal subunits and assuming that both subunits can be considered as nearly spherical particles, radii of about $135 \AA$ and $110 \AA$ can be calculated for the $60 S$ and $40 S$ particle respectively. As can be seen from table 3.1 the value of $w Z=4 / 3 \pi R^{3} w \rho$ is within this region nearly independent of the dissociation and association reactions. The results of these calculations are strongly supported by the finding of Choi and $\mathrm{Carr}^{3}$ that the ribosomal subunits of the ribosomes of Escherichia coli have identical binding curves. Hence it seems reliable to use equation (2), in spite of the dissociation and association reactions. The charge density $\rho$ is proportional to the charge per ribosomal phosphate. It is assumed that the charge of the ribosomes is about +0.1 per ribosomal phosphate when all phosphate groups are occupied with magnesium ions. This is the charge of the ribosomal proteins at a neutral $\mathrm{pH}$. 
Hence the charge density of the ribosomes can be given by:

$$
\rho=\mathrm{a}(\mathrm{r}-1+0.1)
$$

Substituting equation (6) in equation (2) we get:

$$
\mathrm{pMg}=\mathrm{pK}_{\text {int }, \mathrm{Mg}}+\log \frac{\beta}{1-\bar{\beta}}-0.868 \mathrm{wz}_{\mathrm{i}} \frac{4}{3} \pi \mathrm{R}^{3} \mathrm{a}(\mathrm{r}-1+0.1)
$$

or:

$\mathrm{pMg}=\mathrm{pK}_{\text {int }, \mathrm{Mg}}+\log \frac{\beta}{1-\beta}-\mathrm{A}(\mathrm{r}-1+0.1)$

As mentioned above $\mathbf{A}$ is independent of the dissociation and association reactions.

\begin{tabular}{|c|r|}
\hline ionic strength & w x 10 \\
\hline 0.1 & 26.4 \\
0.05 & 50.6 \\
0.025 & 95.3 \\
0.010 & 208.3 \\
0.005 & 357.1 \\
\hline
\end{tabular}

Table 3.2. Effect of the ionic strength on $w$, calculated according to equation (5) $R=150$ $\AA$ Other numerical data are the same as in table 3.1.

The effect of the ionic strength on $w$ is shown in table 3.2. As an example the term $-0.868 \mathrm{wz}_{\mathrm{i}} \mathrm{Z}$ was calculated for the maximum value of $\mathrm{Z}$, i.e. about -5000 , at a ionic strength of 0.005 . In this case $-0.868 \mathrm{wz}_{\mathrm{i}} \mathrm{Z}$ became about 31 . This value is unrealistic high. However, Schildkraut and Lifson ${ }^{6}$ showed that the electrostatic potential $\psi-$ and $w$ is directly proportional with $\psi$ - at the surface of a macro-ion is overestimated by the DebyeHückel-approximation, used in the calculation of $\psi$. They suggest that the 
"high local concentration of the counterions in the immediate vicinity of the fixed charges screen these charges from interaction with other fixed charges, to the extent that the system behaves as if the fixed ions carry a reduced charge. The notion of a reduced charge represents in a single parameter the deviation of the Debye-Hückel approximation from the true potential". According to the theory of Schildkraut and Lifson $Z$ has to be replaced by $\lambda Z$. $\lambda$ appears to be constant over a wide range of salt concentrations. The results of Holcomb and Timasheff ${ }^{7}$ suggest that $\lambda$ is also independent of the charge of the macro-ion. Usually $\lambda$ has a value in the range between 0.1 and 0.25 . With a factor within this range more reasonable values of $w$ are obtained.

When there are more classes of binding sites an equation like equation (7) holds fore each class. For instance for two classes of binding sites these equations are:

$$
\mathrm{pMg}=\mathrm{pK}_{\text {int }, \mathrm{Mg}, 1}+\log \frac{\beta_{1}}{1-\beta_{1}}-\mathrm{A}(\mathrm{r}-1+0.1)
$$

and

$$
\mathrm{pMg}=\mathrm{pK}_{\text {int }, \mathrm{Mg}, 2}+\log \frac{\beta_{2}}{1-\beta_{2}}-\mathrm{A}(\mathrm{r}-1+0.1)
$$

If the equations (8) and (9) are combined, we get:

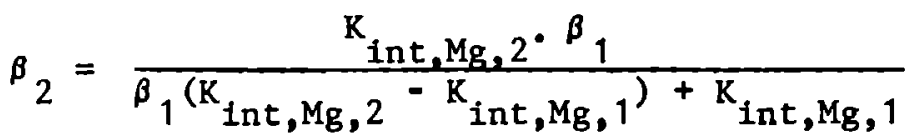

Hence, with known values of $K_{\text {int, }}, g_{g}, 1$ and $K_{\text {int, }},{ }_{g g}, 2, \beta_{2}$ can be expressed in $\beta_{1}$. In the calculation procedure values for $\beta_{1}$ are chosen and the corresponding values of $\beta_{2}$ are calculated according to equation (10). If the number of binding sites of each class is known (these numbers, expressed in equivalents magnesium per ribosomal phosphate, can be read from the experimental binding curve; see section 3.4 ) the charge $r-1+0.1$ can be calculared. Finally, with a known value of $\mathrm{A}, \mathrm{pMg}$ is calculated according to equation (8) or (9). $\mathrm{K}_{\mathrm{int}, \mathrm{Mg}, 1}, \mathrm{~K}_{\mathrm{int}, \mathrm{Mg}, 2}$ and $\mathrm{A}$ are found by trial and error to fit the experimental data. 


\subsection{Results}

In chapter II the possibility that ribosomes have two classes of binding sites has been mentioned. To examine this possibility in more detail a number of binding experiments under a variety of conditions were performed. The results are shown in fig.3.2, fig.3.3 and fig.3.4. The experimental conditions are given in the legends of these figures. In nearly all curves an inflection point at about $r=0.40$ is found. This can only mean that there are two classes of binding sites.
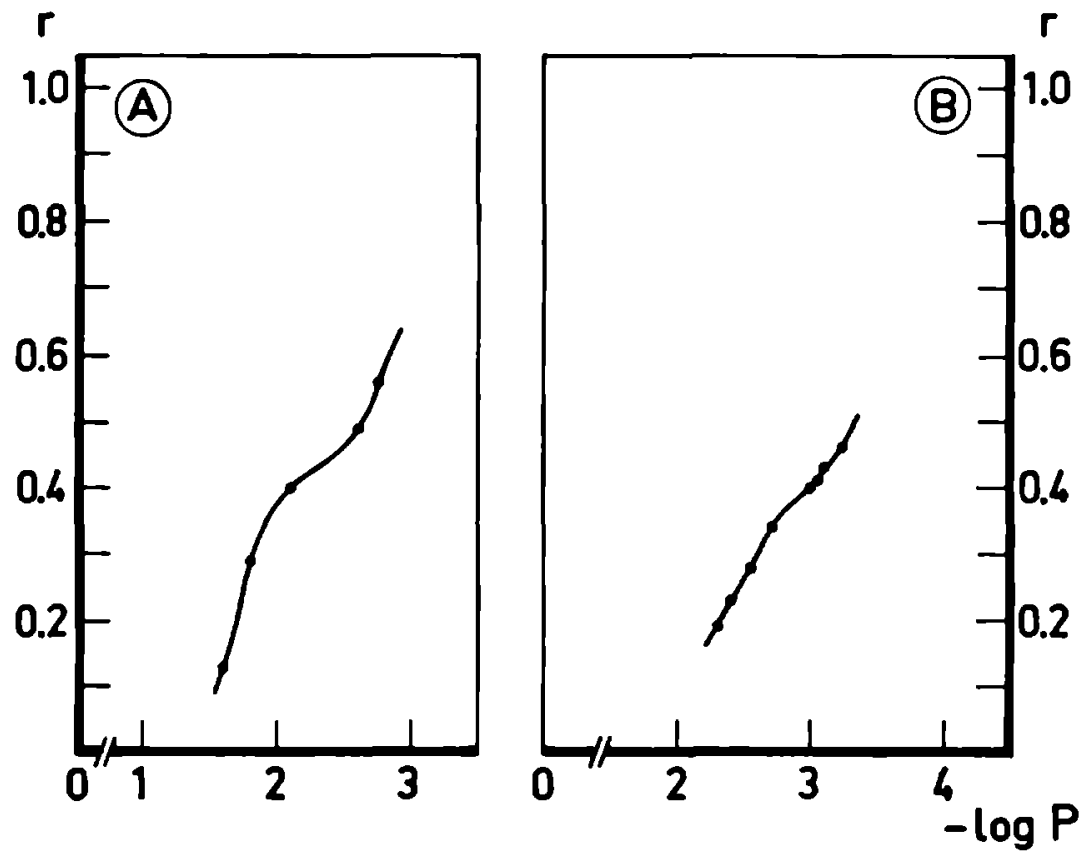

Fig.3.2. Effect of the concentration $P$ of the phosphate buffer $(\mathrm{pH}=7.4)$ on $\mathrm{Mg}^{++}$-binding to yeast ribosomes at a constant free magnesium ion concentration.
$A:\left[\mathrm{Mg}^{++}\right]=2 \times 10^{-4}$
$\mathrm{B}:\left[\mathrm{Mg}^{++}\right]=10^{-5}$ 

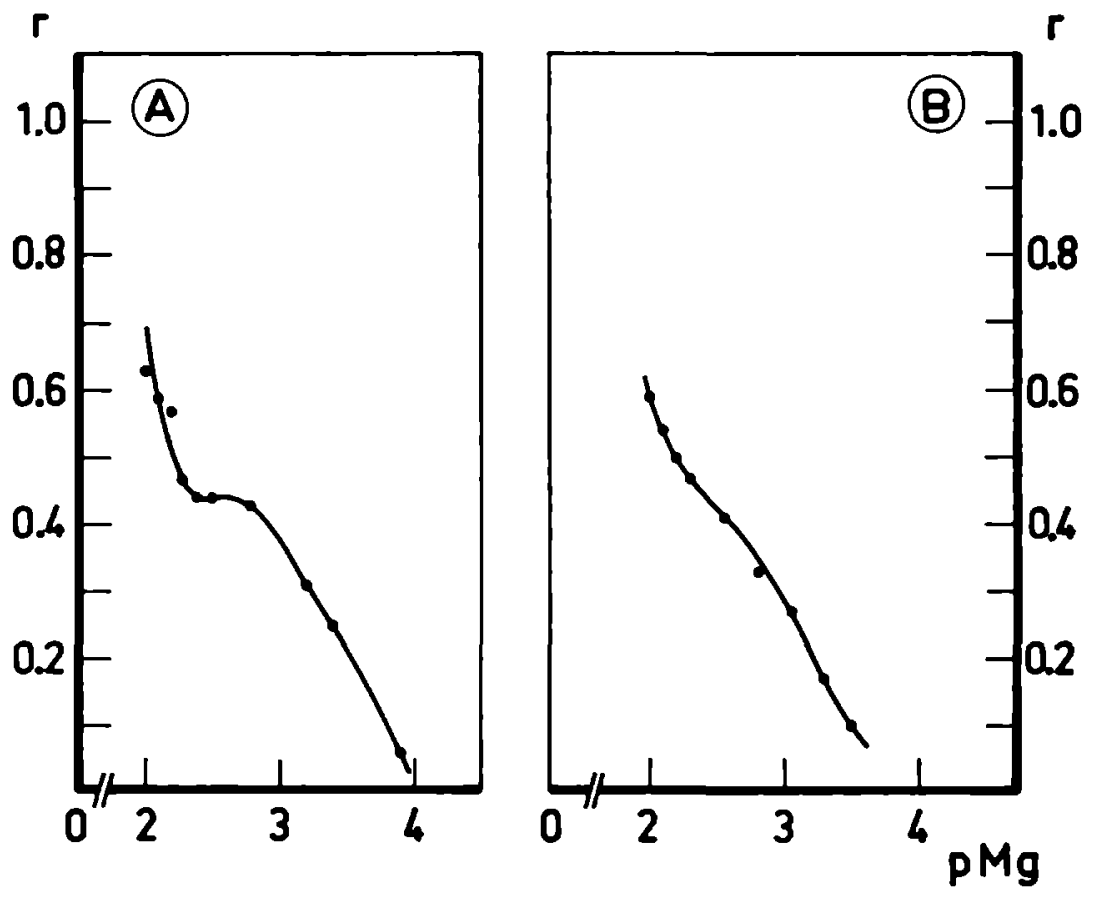

Fig.3.3. Effect of $\mathrm{pMg}$ on $\mathrm{Mg}^{++}$-binding to yeast ribosomes at a constant ionic strength of 0.1. A and B: duplicate experiments on different ribosomes preparations. 

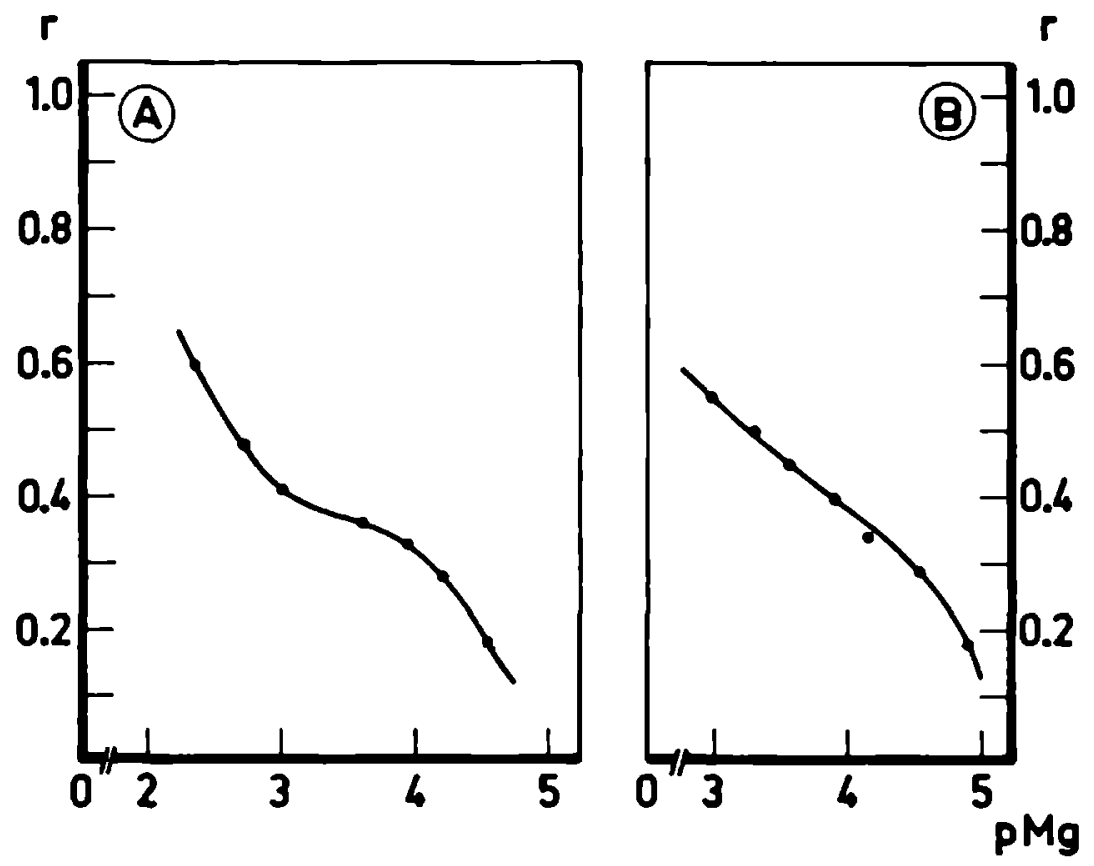

Fig.3.4. Effect of $\mathrm{pMg}$ on $\mathrm{Mg}^{++}$-binding to yeast ribosomes at a constant phosphate buffer concentration.
A : $0.01 \mathrm{~m}$ phosphate buffer $(\mathrm{pH}=7.4)$.
B : $0.002 \mathrm{~m}$ phosphate buffer $(\mathrm{pH}=7.4)$. 


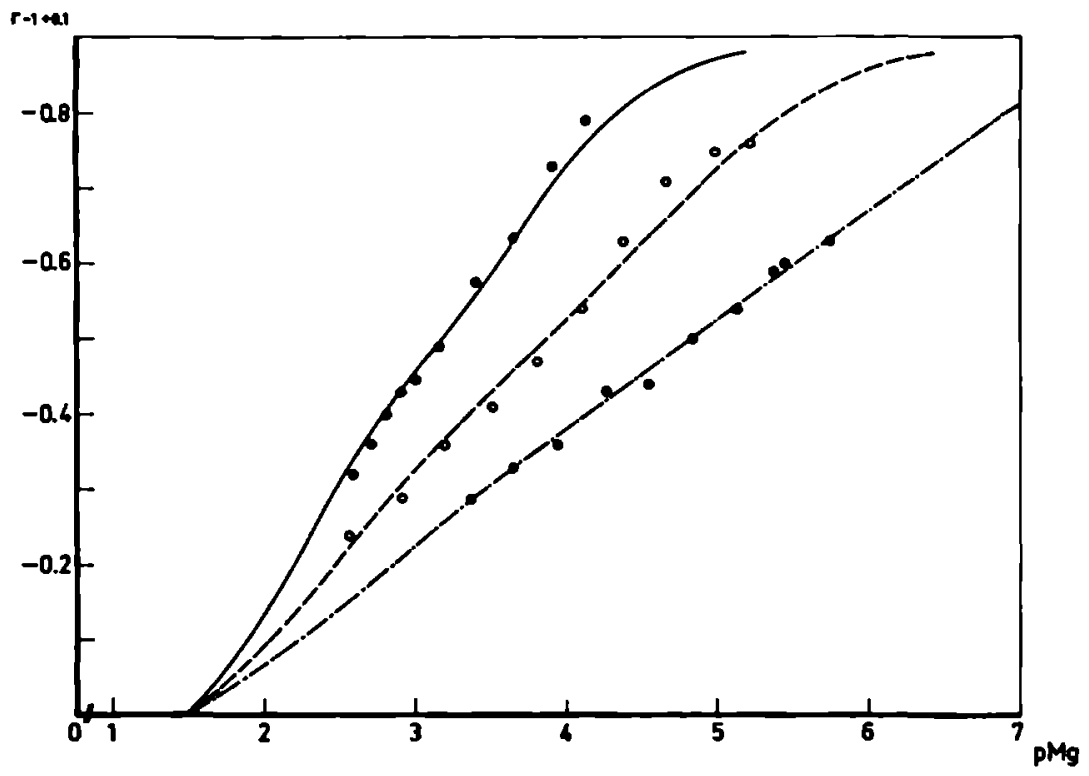

Fig.3.5. Charge of the ribosomes, expressed in equivalents per ribosomal phosphate, versus pMg.

The lines are calculated with $\mathrm{pK}_{1}=2.17, \mathrm{pK}_{2}=3.77, \mathrm{n}_{1}=0.57$ and $\mathrm{n}_{2}=0.43$. The points are found experimentally

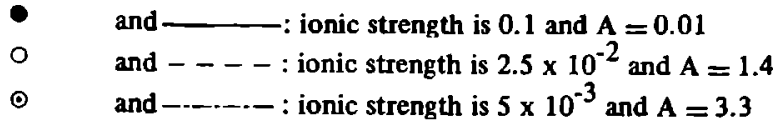

In calculating the experimental values of $\mathrm{pMg}$ activities instead of concentrations were used. 
To examine the effect of the salt concentration on the amount of bound magnesium ions, binding experiments were carried out at ionic strengths of $10^{-1}, 2.5 \times 10^{-2}$ and $5 \times 10^{-3}$ respectively. To eliminate variations between different ribosome-populations the binding experiments were performed with the same ribosome-population. Fig. 3.5 shows the charge of the ribosomes as a function of $\mathrm{pMg}$ for the three different values of the ionic strength. The points are found experimentally. The lines are calculated using $n_{1}=0.57, n_{2}$ $=0.43,\left(n_{1}\right.$ and $n_{2}$ are the number of binding sites of the two classes respectively, expressed in equivalents per ribosomal phosphate; hence $n_{1}+n_{2}=1$ ) $\mathrm{pK}_{1}=2.17$ and $\mathrm{pK}_{2}=3.77$. The values of $\mathrm{A}$ are $0.01,1.4$ and 3.3 for a ionic strength of $10^{-1}, 2.5 \times 10^{-2}$ and $5 \times 10^{-3}$ respectively. It is seen that a reasonable fit with the experimental data is obtained.

\subsection{Discussion}

In this section some statements and results of section 3.4 will be discussed in more detail.

\subsubsection{The nature of the binding of magnesium ions to yeast ribosomes}

In the analyses of our binding experiments we have proposed that mag. nesium ions are bound to the ribosomal phosphate groups. However, with regard to the interaction of small ions to macro-ions two kinds of binding can be distinguished. First small ions can be bound to a well-defined site of the macro-ion. This type of binding is called "site-binding" or "specific binding". It is comparable with, for instance, the binding of $\mathrm{H}^{+}$-ions to acetate ions. Second there can be binding due to the electrostatic potential of the macroion. This type of binding is called "non-specific binding" or "diffuse binding". It is comparable with the interaction of $\mathrm{Na}^{+}$-ions with acetate ions. Experimentally it is almost impossible to distinguish site binding and diffuse binding and in binding experiments both effects are measured together. However, the finding of Willemsen ${ }^{8}$ that at about $\mathrm{pH}=10$ the binding of magnesium ions to polyadenylic acid and to polyuridylic acid is nearly identical, in spite of the quite different charge densities of the two poly-electro ly tes, seems a strong indication that, at least in the presence of monovalent cations, the binding of magnesium ions to ribonucleic acids is a specific binding and that the contribution of non-specific binding can be neglected. In the 
following sections we will understand by binding only site binding.

\subsubsection{Two classes of binding sites}

In section 3.4 evidence was presented that there are two classes of binding sites. At present it seems unlikely that these two classes have to be associated with a participation of the $\mathrm{NH}_{2}$-groups of some oases in the interaction between rRNA and magnesium ions since spectro-chemical studies indicated that the bases of polynucleotides are not involved in the binding of magnesium ions 9 . Nevertheless the existence of two classes of binding sites includes that not all phosphate-groups are identical. Indeed in rRNA two conformations exist, viz. double-helical regions and single stranded non-helical regions to which most probably the ribosomal proteins are bound.

The helical content of yeast rRNA was estimated to be about 60 per cent ${ }^{10}$, hence the non-helical content is about 40 per cent. It is a striking fact that the two classes of binding sites contain about 60 per cent and 40 per cent of the phosphate-groups respectively. This suggests that the two classes of binding sites might reflect the two different conformations which occur in rRNA.

The finding of two classes of binding sites presents a reasonable explanation for the inflection points as found in the plots of $\alpha$ versus $\mathrm{pMg}$ in chapter II. As indicated in chapter II these inflection points correspond with about $r=0.40$. In fact these finding support our conclusion that the dissociation of yeast ribosomes is controlled by the total electrical charge of the ribosomes.

\subsubsection{The effect of monovalent cations}

In section 3.4 an experiment was described concerning the binding of magnesium ions by yeast ribosomes at different salt concentrations (fig. 3 5). From this experiment it will be clear that the ionic strength has a marked effect on the extent of magnesium binding. As already mentioned in chapter II, it is still a matter of discussion whether this effect is a pure ionic strength effect or a competitive effect. It has been shown that a competitive effect results in an apparent alteration of the intrinsic dissociation constant ${ }^{5}$. In equation ( 7 ) $\mathrm{K}_{\mathrm{int}}, \mathrm{Mg}$ has to be replaced by:

$$
K_{\text {int, Mg }}\left(1+\frac{e^{-2 w z_{B} Z}}{K_{i n t, B}} c_{B}\right) \text {, }
$$


where $\mathrm{z}_{\mathrm{B}}=$ the charge of the cation $\mathrm{B}$ that can compete with magnesium ions; $K_{i n t, B}=$ the intrinsic dissociation constant of this cation and $c_{B}$ its concentration. For small values of $\mathrm{Z}, \mathrm{K}_{\mathrm{int}}, \mathrm{Mg}$ can be replaced by:

$$
\mathrm{K}_{\text {int }, \mathrm{Mg}}\left(1+\frac{\mathrm{c}_{\mathrm{B}}}{\mathrm{k}_{\text {int }, \mathrm{B}}}\right)
$$

It will be clear that at about $Z=0$ a competitive effect will not cancel, while under these conditions a pure ionic strength effect will cancel since $0.868 w z_{\mathrm{i}} \mathrm{Z}$ approaches zero. It appeared that a reosonable fit with the experimental data could be obtained by using the same pK-values for the different salt concentrations, indicating that the effect of monovalent cations can be explained as a pure ionic strength effect and that the assumption of a competitive effect is not necessary. However, since the solution given is not unique a real competitive effect between potassium and magnesium ions can not be excluded. For a. sound argumentation the experimental curves of fig.3.5 should be extended to higher magnesium ion concentration. If then the three curves would intersect at about $Z=0$ no competitive effect should exist. Unfortunately such an extension of the experimental curves is in practice impossible. At high magnesium ion concentrations the difference between the magnesium ion concentrations within the dialysis bag and those in the buffer is very small and hence the error in the experimental value of the amount of bound magnesium ions very large. In addition, at a low ionic strength the upper limit of the concentration of free magnesium ions is determined by the desired ionic strength.

The effect of monovalent cations has been explained as a competitive effect by Choi and Carr ${ }^{3}$. These authors, in a study of magnesium binding to E.coli ribosomes, claim a weaker binding for monovalent cations than for divalent cations, but they pay no attention to the fact that a decrease of the magnesium binding with an increase in the concentration of monovalent cations might be caused by an alteration of the electrostatic interaction between the binding sites. Goldberg ${ }^{2}$ found that for E.coli ribosomes the extent of magnesium binding at a free magnesium concentration of $6 \times 10^{-3} \mathrm{M}$ is the same in the presence of $10^{-1}$ and $10^{-2} \mathrm{M}$ potassium chloride respectively. This finding seems not compatable with the idea of a competitive effect between potassium and magnesium ions. There is another argument that monovalent cations are not bound by polynucleotides. Ross and Scruggs ${ }^{11}$ calculated the effective charge per DNAP (= phosphate groups of desoxyribonucleic acid) 
from electrophoresis experiments in the presence of $\mathrm{TMA}^{+}$(= tetramethylammonium), $\mathrm{K}^{+}, \mathrm{Na}^{+}$and $\mathrm{Li}^{+}$respectively. Though the effects of these monovalent cations were not completely the same, it is remarkable that the charge per phosphate-group did not alter over the range $0.05-0.4 \mathrm{M}$. Since in the case of binding the effective charge should decrease with increasing counterion concentration, this suggests in the author's opinion that the monovalent cations are not bound at all. On the other hand the results of Ross and Scrugg are easily explained by the theory of Schildkraut and Lifson ${ }^{6}$ as mentioned in section 3.3. All together the conclusion seems justified, that monovalent ions are not bound. 


\section{References}

1. M.L. Petermann, The Physical and Chemical Properties of Ribosomes, Elsevier, Amsterdam (1964).

2. A. Goldberg, J. Mol. Biol., 15 (1966) 663.

3. Y.S. Choi and C.W. Carr, J. Mol. Biol., 25 (1967) 331.

4. J. Steinhardt and S. Beychok, in H. Neurath, The proteins, Vol III, Academic Press, New York and London, second edition, (1964).

5. C. Tanford, Physical Chemistry of Macromolecules, John Wiley and Sons, New York (1965).

6. C. Schildkraut and S. Lifson, Biopolymers, 3 (1965) 195.

7. D.N. Holcomb and S.N. Timasheff, Biopolymers, 6 (1968) 513.

8. A.M. Willemsen, Thesis, University of Nijmegen, The Netherlands (1969).

9. J.W. Lyons and L. Kotin, J. Am. Chem. Soc., 87 (1965) 1781.

10. R.I. Cotter, P. McPhie and W.B. Gratzer, Nature, 216 (1967) 864.

11. P.D. Ross and R.L. Scruggs, Biopolymers, 2 (1964) 231. 


\section{Summary}

The aim of the present investigation was to obtain more information about the bonds involved in holding ribosomal subunits together and about the mechanism of the dissociation-association reaction of yeast ribosomes.

In chapter I a survey with regard to the chemical composition and the structure of ribosomes has been given.

In chapter II the dissociation-association behaviour of yeast ribosomes is described. The dissociation has been studied quantitatively as a function of bound magnesium ions and as a function of bound hydrogen ions. Making the reliable assumption that monovalent cations - except hydrogen ions - are not bound to ribosomes, it can be concluded from our experiments that the degree of dissociation is a function of the total electrical charge only. It seems irrelevant whether this charge is located on the RNA-chains or on the proteins.

Association can only occur when a sufficient fraction of the charge has been neutralized, either by increasing the magnesium ion concentration or by decreasing the $\mathrm{pH}$. From these results it may be concluded that the association reaction is also controlled by the electrical charge of the ribosomes. There seems no reason to believe that magnesium ions or other divalent cations have a direct binding function in holding the ribosomal subunits together, but since it has been reported in the literature that strontium- and barium ions could not replace magnesium ions, the effects of these cations are also examined. It appears that these cations cause some structural changes, which make any interpretation of the effects of these cations on the dissociation and association behaviour impossible.

Conceming the dissociation and association behaviour it is found that this reaction is not a real equilibrium reaction. However, neither by means of the measurement of the optical rotatory dispersion and circular dichroism, nor with measurements of the sedimentation coefficients any alteration in the ribosomal structure - besides the dissociation into subunits - could be detected. Hence the difference in the dissociation and the association behaviour is probably not caused by changes of the ribosomal structure, but it is shown that a combination of long-range repulsion forces and short-range attraction forces can explain at least qualitatively this hysteresis. Hence, we suppose that the ribosomal subunits are linked together by short-range forces, such as hydrogen bond or hydrophobic interactions. 
Because the dissociation and the association reactions require larger differences in ionic conditions than probably can occur in living cells, the possible existence of a dissociation factor in the living cells of yeast is discussed.

From our experiments it appeared that there is some kind of heterogeneity in the ribosome populations. The significance of this phenomenon is still not clear.

Chapter III deals with a theoretical and experimental analysis of the binding of magnesium ions by yeast ribosomes. This study is made to check the statement of chapter II that monovalent cations are not bound by yeast ribosomes. In the theoretical considerations the interactions between charges located on a macro-ion are included. In the calculations these interactions result in a term, in which both the charge and the radius of the macro-ion are accounted for. It appears that on dissociation of the ribosomes both the charge and the radius change, but in such a way, that the term, which accounts for the electrostatic interactions, remains constant. As a consequence the dissociation can be neglected in the analyses of the binding experiments.

Our experiments indicate that two binding reactions between ribosomes and magnesium ions occur. The endpoints of these reactions correspond with about 0.40 and 1.0 equivalent magnesium per ribosomal phosphate respectively. The pK-values are about 3.8 and 2.2 respectively.

The experimental results indicate that the effect of monovalent cations can be explained as a pure ionic strength effect, though the binding of monovalent cations could not be excluded completely. However, some literature data also suggest that monovalent cations are not bound by nucleic acids. 
Samenvatting

Het in dit proefschrift beschreven onderzoek had tot doel na te gaan welk soort bindingskrachten er tussen ribosomale subeenheden bestaan. Bovendien werd getracht meer inzicht te verkrijgen in het mechanisme van de dissociatie en associatie reacties.

Hoofdstuk I geeft een overzicht van de huidige kennis van de chemische samenstelling en de structuur van ribosomen.

Hoofdstuk II beschrijft een experimenteel onderzoek naar het dissociatie-associatie gedrag van gistribosomen. De dissociatiegraad is kwantitatief bepaald als functie van het aantal aan de ribosomen gebonden magnesiumionen en als functie van de gebonden waterstofionen. Met de redelijke aanname, dat eenwaardige ionen - uitgezonderd $\mathrm{H}^{+}$-jonen - niet aan ribosomen gebonden worden, kan uit de experimenten geconcludeerd worden dat de dissociatiegraad alleen bepaald wordt door de lading van het ribosoom. Het doet hierbij niet ter zake of de lading gelocaliseerd is op de rRNA-ketens of op het ribosomale eiwit.

Associatie vindt alleen plaats als de lading voldoende ver geneutraliseerd is. Dit kan bereikt worden door de concentratie van magnesium ionen te verhogen of door de $\mathrm{pH}$ te verlagen. Uit de uitgevoerde experimenten blijkt dat ook de associatie uitsluitend door de lading bepaald wordt. Wij kunnen geen enkel argument aanvoeren, dat er op wijst dat tweewaardige kationen een directe rol spelen bij het bijeenhouden van de ribosomale subeenheden, maar omdat in de literatuur is beschreven dat strontium- en bariumionen niet in staat zijn de functie van magnesiumionen over te nemen, is ook het effect van deze ionen onderzocht. Het blijkt dat deze kationen structurveranderingen veroorzaken, zodat over het effect van deze ionen op de dissociatie en associatie reacties geen conclusies getrokken kunnen worden.

De dissociatie-associatie reactie blijkt geen evenwichtsreactie te zijn. Noch door meting van optische rotatie-dispersie en circulair dichroisme, noch door meting van de sedimentatieconstanten kon echter een structuurverandering worden aangetoond. Het lijkt daarom niet waarschijnlijk dat het verschil in het dissociatie en het associatie gedrag door structuurveranderingen wordt veroorzaakt, maar wel kon worden aangetoond dat door "samenwerking" van ver-dragende electrostatische repulsiekrachten en kortdragende aantrekkende krachten tussen twee deeltjes de hysterese verklaard kan worden. Daarom wordt verondersteld dat de bindingskrachten kortdragende krachten zijn, zoals bijvoorbeeld waterstofbruggen of hydrophobe interacties. 
De omstandigheden die nodig zijn voor de dissociatie verschillen nogal van die voor associatie. Het lijkt niet waarschijnlijk dat dergelijke verschillen in een levende cel kunnen optreden. Het is dan ook mogelijk, dat de dissociatie en associatie in een levende cel op een andere manier geregeld worden. Gedacht wordt aan een dissociatiefactor zoals die ook in de cellen van E-coli voorkomt.

Experimenteel is gebleken dat de ribosomen populatie heterogeen is. De betekenis van deze waarneming is nog niet duidelijk.

Hoofdstuk III handelt over een theoretische en experimentele analyse van de binding van magnesiumionen aan gistribosomen. Dit onderzoek werd vooral uitgevoerd om de veronderstelling dat eenwaardige ionen niet gebonden worden aan ribosomen, na te gaan. Bij de theoretische behandeling wordt rekening gehouden met electrostatische interacties tussen de ladingen, die op het macromolecuul gelocaliseerd zijn. Deze interacties komen in de berekeningen tot uiting in een term, die zowel de lading als de straal van het macromolecuul bevat. Het blijkt dat bij dissociatie van ribosomen, die optreedt bij lage concentraties van magnesiumionen, zowel de lading als de straal verandert, en wel zodanig dat de interactie-term constant blijft. Met de dissociatie behoeft daarom bij de analyse van de bindingsexperimenten geen rekening gehouden te worden.

Uit de experimentele curves volgt dat er twee bindingsreacties tussen magnesium ionen en ribosomen bestaan. De eindpunten van deze reacties liggen ongeveer bij 0.40 en 1.00 aequivalenten magnesium per ribosomale fosfaatgroep. De pK-waarden zijn ongeveer 3.8 en 2.2 .

De invloed van eenwaardige kationen op het aantal gebonden magnesiumionen kan geinterpreteerd worden als een ionsterkte-effect, hoewel onze experimenten binding van eenwaardige ionen niet geheel uitsluiten. Er worden echter enige literatuurgegevens besproken die er ook op duiden dat eenwaardige ionen niet door nucleinezuren worden gebonden. 


Bauld en Brown concluderen ten onrechte uit hun experimenten dat reductie van het tweewaardige anion van dibenzoylmethaan met natrium een volledige omzetting in het driewaardige anion tot gevolg heeft.

N.L. Bauld en M.S. Brown, J. Am. Chem. Soc., 89 (1967) S413.

De door Karpenko en medewerkers beschreven methode voor het bepalen van de binding van anorganische ionen aan eiwitten uit metingen van het geleidingsvermogen is dermate onbetrouwbaar, dat aan deze methode geen practische betekenis kan worden toegekend.

\author{
V. Karpenko, V. Kalous en Z. Pavlī̌ek, \\ Collection Czechoslov. Chem. Commun., \\ 33 (1968) 3457.
}

De mening van Dietz en Scholz dat er, voor de door hen onderzochte verbindingen, een relatie bestaat tussen de som van de vrije valentie getallen van de bij een fotodehydrocyclisering betrokken koolstofatomen. berekend voor de eerste aangeslagen toestand, en de experimenteel gevonden opbrengst, is gebaseerd op een onjuiste interpretatie van hun experimenten.

F. Dietz en M. Scholz. Tetrahedron, 24 (1968) 6845.

\title{
IV
}

De beschouwing die Spahr en Edsall, in verband met de door hen gevonden aminozuursamenstelling van menselijk en van runder serumalbumine, wijden aan de waarde van de isoionische $\mathrm{pH}$ is niet juist.

P.F. Spahr en J.T. Edsall, J. Biol. Chem., 239 (1964) 850. 
Bij de bestudering van binding van kleine ionen aan macromoleculen wordt veelal een verandering in de solvatatie van de ionen beschouwd als een indicatie voor "specifieke binding". Aangezien niet duidelijk vaststaat dat dit effect afwezig is bij niet specifieke - of ionenatmosfeerbinding, is een verandering van solvatatie een onbetrouwbare maatstaf voor de aard van de binding.

$$
\begin{aligned}
& \text { J.W. Lyons en L. Kotin, J.Am. Chem. Soc., } 87 \text { (1965) } 1670 . \\
& \text { U.P. Strauss en Y.P. Leung, J.Am. Chem. Soc., } 87 \text { (1965) } 1476 .
\end{aligned}
$$

De door Fedorovich en Ostrovskii gebruikte methode ter bepaling van de natrium-kalium-geactiveerde ATP-ase activiteit in de retina is onbetrouwbaar.

I.B. Fedorovich en M.A. Ostrovskii
Biofizika, 13 (1968) 449.

VII

De vaak gebruikte formulering van de consecratie-woorden: "neemt en eet, dit is mijn lichaam voor u", houdt een onaanvaardbare dubbelzinnigheid in voor hen die in de thomistische transsubstantiatieleer geloven. 

